DANMARKS GEOLOGISKE UNDERSØGELSE IV. RÆKKE. B D. 4. NR. 9

Geological Survey of Denmark. IV. Series. Vol. 4. No. 9

\title{
Clay Mineralogy \\ of some Lower Tertiary (Paleogene) Sediments from Denmark
}

\author{
by \\ R. W. Tank \\ Med \\ dansk sammendrag
}

C. A. REITZELS FORLAG (JØRGEN SANDAL)

KøBENHAVN 1963 


\section{Table of Contents}

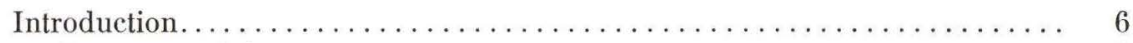

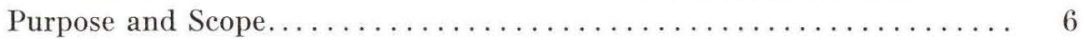

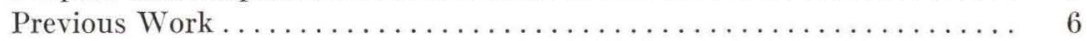

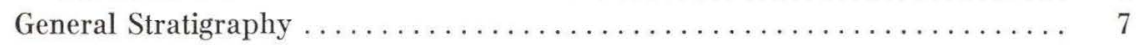

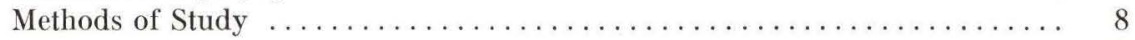

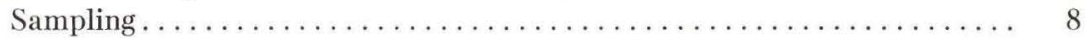

Standard Preparation................................. 12

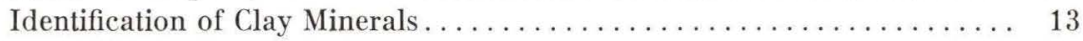

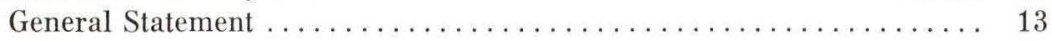

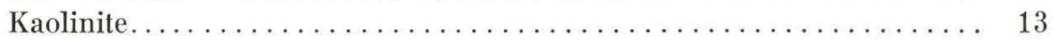

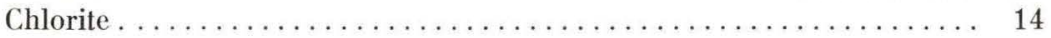

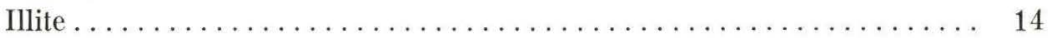

Montmorillonite............................. 14

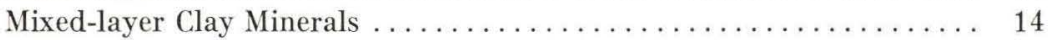

Semi-quantitative Analysis . . . . . . . . . . . . . . . . . . . 15

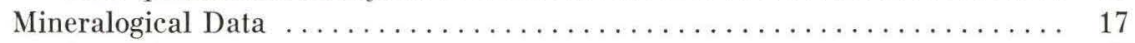

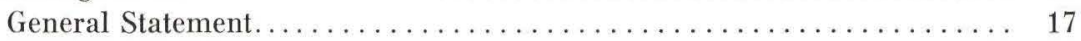

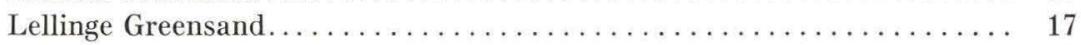

Kerteminde Clay................................ 19

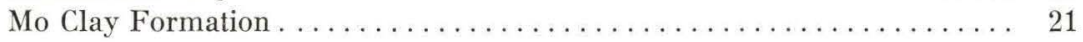

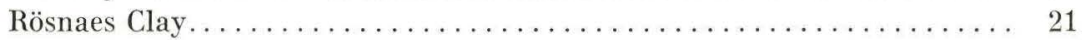

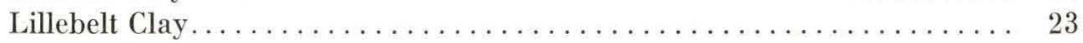

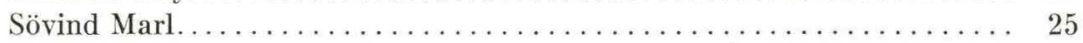

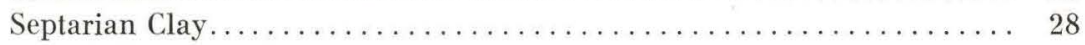

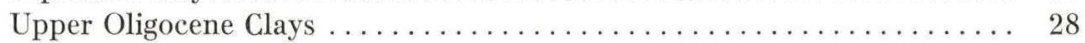

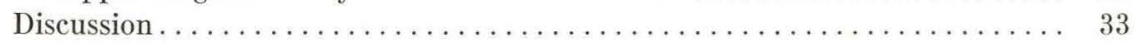

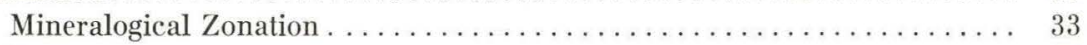

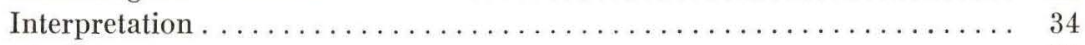

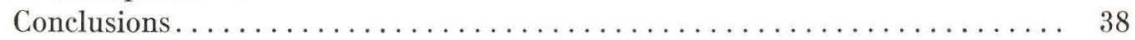

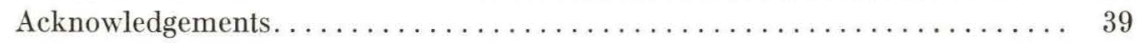

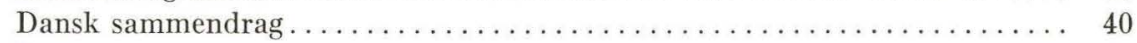

References Cited.................................. 44

\section{Tables}

1. Lower Tertiary (Paleogene) Stratigraphy of Denmark............ 9

2. Summary of Clay Mineral Composition of Lellinge Greensand ....... 19

3. Summary of Clay Mineral Composition of Kerteminde Clay.... . . . . . 19

4. Summary of Clay Mineral Composition of Mo Clay Formation. . . . . . 23 
5. Summary of Clay Mineral Composition of Rösnaes Clay........... 23

6. Summary of Clay Mineral Composition of Lillebelt Clay............ 25

7. Summary of Clay Mineral Composition of Sövind Marl ........... 25

8. Summary of Clay Mineral Composition of Septarian Clay . .......... 28

9. Summary of Clay Mineral Composition of Upper Oligocene Clays . . . . . 31

10. Mineralogical Zonation of the Danish Paleogene................ 33

\section{Figures}

1. Sketch map of Denmark showing location of collecting sites mentioned in

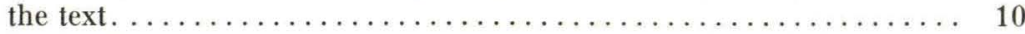

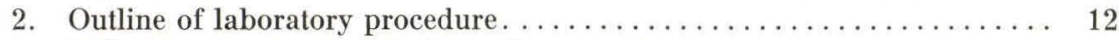

3. Diffractometer traces - Lellinge Greensand ................. 18

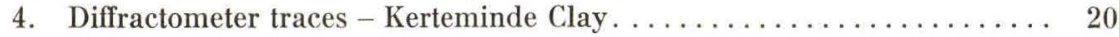

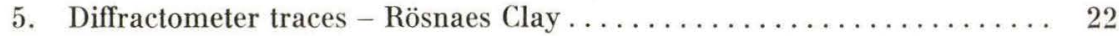

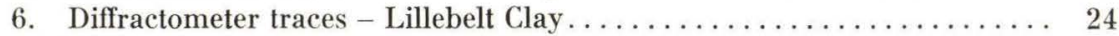

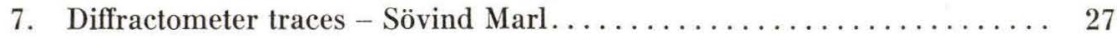

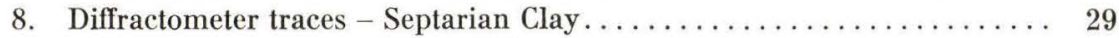

9. Diffractometer traces - Upper Oligocene Clay............... 30

10. Lithologies and average clay mineral composition of some Paleogene sediments from Denmark............................ 32 


\section{Abstract}

108 samples from the Paleogene rocks of Denmark were examined by standard $\mathrm{X}$-ray techniques and their clay suites form the basis of the present study. The $\mathrm{X}$-ray data have permitted a three-fold mineralogical zonation of the Danish Paleogene.

The oldest zone (Zone I) is characterized by a high montmorillonite content, minor or trace amounts of illite and segregated mixed-layer clay minerals and the absence of kaolinite. The boundaries of Zone I coincide with the Paleocene Series. The clay minerals are detrital and are derived from a carbonate terrain bordering the Fennoscandian massif. Diagenetic changes in the marine environment and segregation by sorting and floculation are important factors accounting for the high montmorillonite content.

A middle zone (Zone II) is characterized by the predominance of amorphous material. Minor amounts of montmorillonite, illite and kaolinite are present and represent alteration products of volcanic ash. Zone II is restricted to the Mo Clay Formation.

The youngest zone (Zone III) contains variable amounts of montmorillonite, illite, kaolinite and random mixed-layer montmorillonite-illite. The boundaries of Zone III appear to extend from the lower Eocene to the Miocene. The clay minerals of Zone III are products of the alteration of the volcanic material of the Fennoscandian massif. Changes in the conditions of the source area and the physical environment of deposition account for the mineralogical variations. 


\section{Introduction}

\section{Purpose and Scope.}

The application of clay mineral studies to geologic problems has achieved great importance in the last few decades, and the literature on the subject has begun to grow (see especially Grim, 1953 and Weaver, 1959). The value of clay mineralogy as a geologic tool lies in the fact that the characteristics of clay minerals in ancien sediments may reflect both their source and environmental history.

Clay mineral studies are particularly applicable to the lower Tertiary sediments of Denmark which are typically developed as a sequence of monotonous, variegated, unctuous clays. There have been few systematic mineralogical investigations, and inasmuch as these sediments record one of the most complete marine sequences of lower Tertiary rocks in the North Sea Basin, the desirability of more accurate identification and correlation is apparent.

In September, 1959, dr. phil. P. Graff-Petersen of the University of Copenhagen and members of the Geological Survey of Denmark proposed a systematic biostratigraphic and mineralogical investigation of a portion of the Danish Tertiary. At that time cand. mag. A. Dinesen of the Survey was engaged in a study of the foraminiferal fauna of some Paleogene sediments from Jutland. The writer then began his investigation of the clay mineralogy of the Danish Paleogene. The objectives of the clay mineral investigations were:

1. Determination of the clay minerals that constitute the lower Tertiary sediments of Denmark;

2. Refinement of existing knowledge concerning the stratigraphic subdivisions of the lower Tertiary of Denmark;

3. Improvement of concepts concerning the genetic significance of clay minerals.

\section{Previous Work.}

There have been few systematic investigations of the clay mineralogy of the lower Tertiary sediments of Denmark. The most significant investigations are those of Clausen (1932), Unmack $(1944,1949)$ and Graff-Petersen (1955). Clausen studied samples from the Kerteminde Clay and the "Plastic Clay Group" and his investigations represent a pioneering effort in clay petrology. Unmack's investigations included seven samples from the Eocene Mo Clay Formation, eight samples of the Eocene "Plastic Clay Group" and one sample of an Oligocene clay. GraffPetersen conducted a comprehensive investigation of the clay mineralogy of Eocene samples which were recovered from borings in the Little Belt near Rögle Klint. 


\section{General Stratigraphy}

Various stratigraphic classifications have been used for the subdivision of the Tertiary deposits of northern Europe. The terminology and classification outlined in Lexique Stratigraphique International (Vol. I: Europe, Fascicule 2d, Denmark) is followed, with only slight modifications, in this text and summarized in table 1. The reader is referred to Lexique Stratigraphique International for detailed descriptions of the stratigraphic units and for a bibliography of literature pertaining to the Danish Paleogene.

A monotonous sequence of plastic, unctuous, variegated clays occurs above the Paleocene clay. These strata are known as the "Plastic Clay Group" and are found widely distributed throughout most of Jutland and parts of Funen, Zealand and some of the smaller Danish islands. According to Sorgenfrei (1957, pp. 26-27) the term "Plastic Clay Group" has been in use for over a century, despite numerous attempts to refine the terminology. He records the following subdivisions:

4. Sövind Marl

3. Lillebelt Clay

2. Rösnaes Clay

1. Clay with tuff

The age and correlation of the "Plastic Clay Group" has long been a perplexing problem, owing partly to the scarcity of macrofossils and partly to the fact that there have been few detailed studies of the microfauna, mineralogy and regional stratigraphic relationships. 


\section{Methods of Study}

\section{Sampling.}

Samples from twelve surface exposures and two borings are included in the study. The collecting sites selected offer the best exposures of the stratigraphic units and every effort was made to obtain fresh, unweathered samples. Many of the surface sections were only recently exposed in quarry operations but some of the samples collected from the natural outcrops may have been subjected to weathering.

The collecting sites considered in this report are listed below and the locations are shown in figure 1.

Locality \#1.

Lellinge, Zealand (approximately $6 \mathrm{~km}$. west of Köge).

Lellinge Greensand (Paleocene).

Approximately 2.5 meters of the Lellinge Greensand crop out in the banks of the stream Köge Aa and the exposure is the type locality for the formation. The exposure was described and sampled by cand. mag. A. Dinesen of the Geological Survey of Denmark and the following six samples were included in the present study:

Sample No. 12305-6073, 12306-6203, 12304-6051, 12303-6178, 12302-6087, 12301-6021.

\section{Locality \#2.}

Copenhagen, Zealand.

Lellinge Greensand(?) - Paleocene.

A sample of sandstone was recovered from recent diggings in the harbor at Copenhagen and was made available to the writer by the Geological Survey of Denmark. The enclosed label reads, "Greensand(?), Paleocene, Kongedybet, Köbenhavns havn, leg. I. Bang, Sept., 1961, D.G. U. \#12313.”

Sample No. 12313.

Locality \#3.

Lundsgaard Klint, Funen (approximately $3 \mathrm{~km}$. southeast of Kerteminde).

Kerteminde Clay (Paleocene).

The Kerteminde Clay crops out below Quaternary deposits at Lundsgaard Klint and this exposure is referred to as the type locality for the formation. Six samples were taken at two meter intervals.

Sample No. K-1a, K-1b, K-2a, K-2b, K-3a, K-3b.

Locality \#4.

Österklint, Fur.

Mo Clay Formation (Eocene).

Four samples from the upper and the lower divisions of the Mo Clay Formation were collected from the outcrop at Österklint, Fur.

Sample No. MF-1, MF-2, MF-3, MF-4.

Locality $\# 5$.

Hanklit, Mors.

Mo Clay Formation (Eocene). 
Table 1. Lower Tertiary (Paleogene) stratigraphy of Denmark.

\begin{tabular}{|c|c|}
\hline Miocene & Klintinghoved Mica Clay \\
\hline \multirow{3}{*}{ Oligocene } & $\begin{array}{l}\text { Cilleborg Clay } \\
\text { Brown fossiliferous clay with mica and glauconite. (Max. } 60 \mathrm{~m} \text {, type } \\
\text { area about } 3 \mathrm{~m} \text { ). }\end{array}$ \\
\hline & $\begin{array}{l}\text { Septarian Clay = Branden Clay } \\
\text { Greenish grey, silty, micaceous, glauconitic, fossiliferous clay with } \\
\text { limestone concretions. (Max. } 90 \mathrm{~m} \text {, type area about } 40 \mathrm{~m} \text { ). }\end{array}$ \\
\hline & $\begin{array}{l}\text { Sövind Marl } \\
\quad \text { Yellowish grey, pyritic marl. Abundant foraminifera. }(10-100 \mathrm{~m}) \text {. }\end{array}$ \\
\hline \multirow{4}{*}{ Eocene } & $\begin{array}{l}\text { Lillebelt Clay } \\
\text { Greenish grey, non-calcareous clay. Generally without visible } \\
\text { bedding. Microfossils scarce. }(50-100 \mathrm{~m}) \text {. }\end{array}$ \\
\hline & $\begin{array}{l}\text { Rösnaes Clay = Refsnaes Clay } \\
\quad \text { Variegated, calcareous clay. Generally without visible bedding. } \\
\text { Abundant foraminifera. }(10-40 \mathrm{~m}) \text {. }\end{array}$ \\
\hline & $\begin{array}{l}\text { Mo Clay Formation (Limfjord area, North Jutland) } \\
\text { Light grey, argillaceous diatomite with interbedded tuff layers, vol- } \\
\text { canic sand and limestone concretions. Contains a variety of organic } \\
\text { remains. (About } 50 \mathrm{~m} \text { ). }\end{array}$ \\
\hline & $\begin{array}{l}\text { Clay with Tuff (outside Limfjord area) } \\
\text { Grey, partly greenish or brownish clay with thin layers of tuff. } \\
(10-20 \mathrm{~m}) \text {. }\end{array}$ \\
\hline \multirow[b]{2}{*}{ Paleocene } & $\begin{array}{l}\text { Kerteminde Clay } \\
\quad \text { Grey, calcareous and non-calcareous, fossiliferous clay. (About } 70 \mathrm{~m} \text { ). }\end{array}$ \\
\hline & $\begin{array}{l}\text { Lellinge Greensand } \\
\text { Greyish green, argillaceous limestone and marl with subordinate } \\
\text { beds of glauconitic, pyritic, friable sandstone. Fossiliferous. (About } \\
9 \mathrm{~m} \text { ). }\end{array}$ \\
\hline Danian & Danian Limestone Group \\
\hline
\end{tabular}

(Modified from Sorgénfréi, 1957)

Four samples from the upper and lower divisions of the Mo Clay Formation were collected from the outcrop at Hanklit, Mors.

Sample No. MH-1, MH-3, MH-5, MH-7.

Locality \#6.|

Rösnaes, Zealand.

Rösnaes Clay (Eocene).

Four samples of the Rösnaes Clay were collected from a two meter cut in the Lemvigh-Müller \& Munck clay quarry near Kongstrup.

Sample No. RC-1a, RC-1b, RC-2a, RC-2b. 


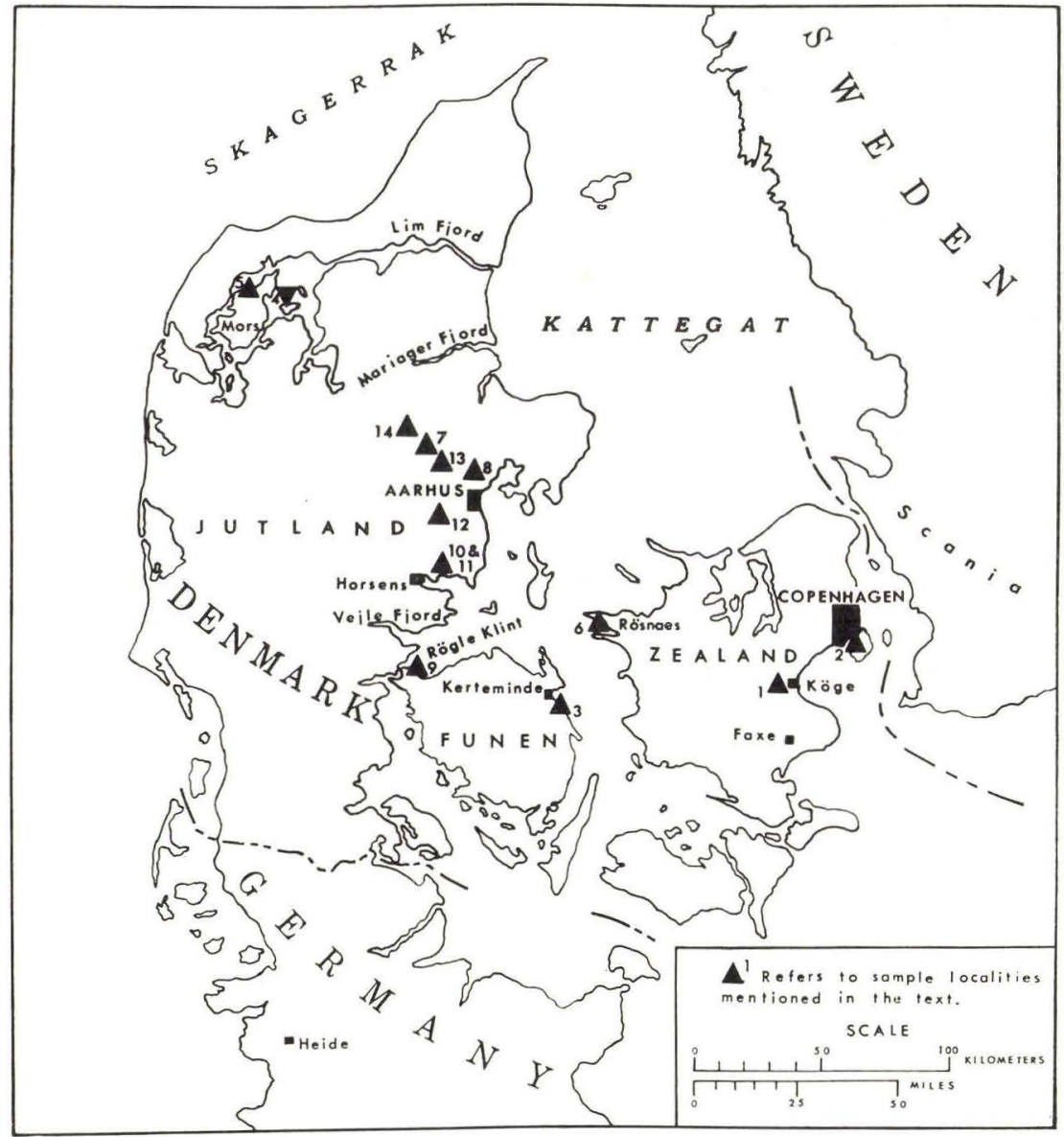

Figure 1. Sketch map of Denmark showing location of collecting sites mentioned in the text.

Locality \#7.

Hinge, Jutland (approximately $21 \mathrm{~km}$. northwest of Aarhus).

Rösnaes Clay (Eocene).

Three samples of the Rösnaes Clay were collected from a 1.5 meter cut in the Leca quarry near Hinge.

Sample No. RL-1a, RL-1b-2, RL-1b-1.

Locality \#8.

Boring at Lille Elsted, Jutland. D.G. U. well file No. 79.174.

Sövind Marl - Eocene-Oligocene(?).

Lillebelt Clay - Eocene.

The boring is located approximately $9 \mathrm{~km}$. north of Aarhus, near Lille Elsted, Jutland. Samples of the Sövind Marl and the Lillebelt Clay were recovered with clay socket. Thirty samples were included in the present study. 
Locality $\# 9$.

Rögle Klint, Funen.

Oligocene sandstone.

Sövind Marl - Eocene-Oligocene (?).

The Eocene "Plastic Clay Group" is exposed along the eastern part of Rögle Klint where it underlies the nearly vertically dipping Oligocene sediments. The writer collected two samples from the Oligocene sandstones and mag. scient. G. Larsen and mag. scient A. Buch of the Geological Survey of Denmark collected a sample of the Sövind Marl from the "Plastic Clay Group".

Sample No. 1017, RK-1, RK-2.

Locality \#10.

Toftum, Jutland (approximately $10 \mathrm{~km}$. northwest of Horsens).

Sövind Marl - Eocene-Oligocene(?).

Approximately 5 meters of the Sövind Marl are exposed in the quarry at Toftum. Three samples were collected from the top three meters of the exposure by cand. mag. A. Dinesen and they are included in the present study.

Sample No. 69813, 69810, 69811.

Locality \#11.

Sövind, Jutland (approximately $10 \mathrm{~km}$. northwest of Horsens).

Sövind Marl - Eocene-Oligocene(?).

Four samples were collected from a 13 meter cut in the quarry near Sövind.

Sample No. S-1-4, S-1-1, S-1-2, S-1-3.

Locality \#12.

Ormslev Kvartsvaerk boring, Jutland. D. G. U. well file No. 88.213.

Miocene(?) siltstone.

Septarian Clay - middle Oligocene.

Sövind Marl - Eocene-Oligocene(?).

The Ormslev Kvartsvaerk boring is located approximately $10 \mathrm{~km}$. southwest of Aarhus, Jutland. Samples of Miocene(?) siltstone, the Septarian Clay and the Sövind Marl were recovered with spiral auger. Thirty-one samples were included in the present study.

Locality \#13.

Grundför, Jutland (approximately $14 \mathrm{~km}$. northwest of Aarhus).

Septarian Clay - middle Oligocene.

Middle Oligocene clay (Septarian Clay) is exposed in the Grundför Brickworks quarry. Five samples from a four meter cut were included.

Sample No. S-3-1, S-3-3, S-3-6, S-3-9, S-3-12.

Locality \#14.

Ulstrupbro, Jutland (approximately $38 \mathrm{~km}$. northwest of Aarhus).

Upper Oligocene clay.

Middle Oligocene clay.

Approximately 10 meters of middle and upper Oligocene beds are exposed in the Sophienlund Brickworks quarry near Ulstrupbro. Four samples were included in the present study.

Sample No. UO-1, UO-2, UO-3b, UO-3a. 


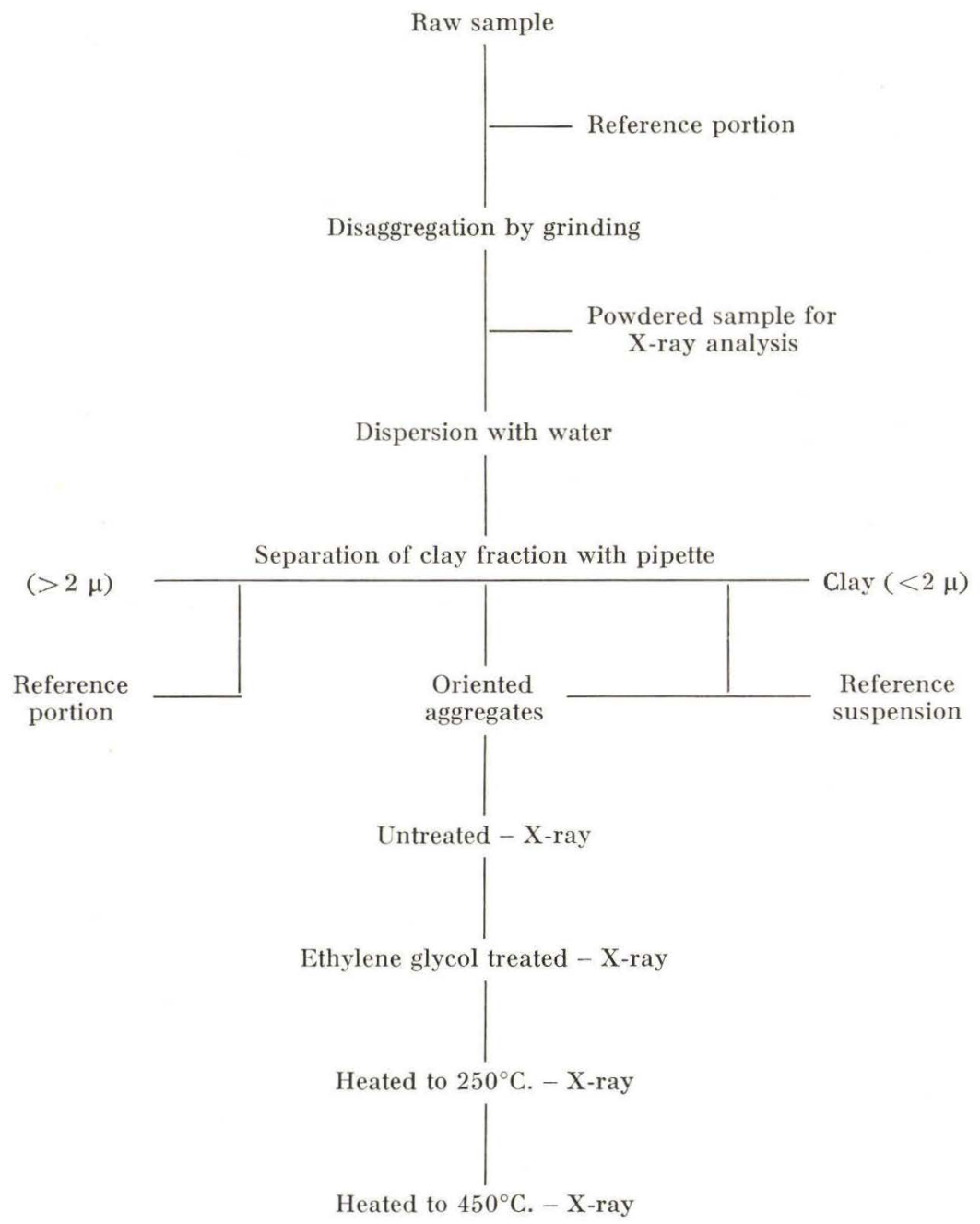

Figure 2. Outline of laboratory procedure.

\section{Standard Preparation.}

The general laboratory procedure is outlined in figure 2. Each raw sample was split into two parts: one part was retained as a reference portion and the other was prepared for mineral analysis by grinding to a fine powder with a mortar and pestle. A portion of the powdered sample was firmly packed in a rectangular sample holder and used for the X-ray identification of the non-clay minerals present in the sample. The remaining powdered sample was used for clay mineral analysis. This latter portion was soaked and agitated in distilled water until the clays were thoroughly 
dispersed. No dispersing agents were used and there was no attempt to remove the carbonates through acid leeching.

A portion of the less than two micron fraction was pipetted onto glass slides and allowed to evaporate to dryness at room temperature. This procedure was utilized in order to obtain a nearly parallel orientation of the clay minerals.

Many of the samples were examined in the clay mineralogy laboratory at the Mineralogical and Geological Institute of the University of Copenhagen. The material was examined on a Philips X-ray diffractometer unit with nickel filtered copper radiation $(\mathrm{CuK} \alpha)$ using an electronically controlled arithmetic recorder. The unit was operated at an accelerating potential of $36 \mathrm{kV}$ and current at $16 \mathrm{~mA}$ with a slit width of $1 \mathrm{~mm}$. Various scale factor: multiplier: time constant ratios were used. All specimens were run to $35^{\circ} 2 \theta$ with a goniometer speed of two degrees per minute. The remaining samples were examined at the clay mineralogy laboratory of Indiana University. At Indiana University the samples were examined on a General Electric XRD-5 diffractometer with nickel filtered copper radiation $(\mathrm{CuK} \alpha)$ using an electronically controlled logarithmic and arithmetic recorder. The accelerating potential was maintained at $50 \mathrm{kV}$ and current at $16 \mathrm{~mA}$ with a slit width of $1 \mathrm{~mm}$. All specimens were run to $50^{\circ} 2 \theta$ with a goniometer speed of two degrees per minute.

In both laboratories diffractometer traces were first made of the untreated, airdried, oriented slides. Diffractometer traces were then made from the same oriented slides after glycolation and after heating to $250^{\circ} \mathrm{C}$. and $450^{\circ} \mathrm{C}$.

A representative number of samples was treated with warm, dilute $\mathrm{HCl}$ (one part acid: one part water) in order to take advantage of the solubility of chlorite in this acid. Selected samples were also saturated with potassium and magnesium salts in order to determine the nature of the expansible minerals.

Several of the glycolated slides examined with the Philips unit were re-examined with the General Electric unit and the diffractometer traces showed no significant differences.

\section{Identification of Clay Minerals.}

General Statement. As in any field of science under active development, differences of opinion have arisen as to the classification and identification of clay minerals. It is desirable therefore to specify the methods used for the identification of the various minerals.

Kaolinite. The kaolinite group of minerals was identified by the well defined regular basal sequence of $7.13 \AA, 3.57 \AA$, and $2.39 \AA$ peaks. Grim (1953, pp. $48-50$ ) discussed the diffraction characteristics of well-crystallized and poorly crystallized kaolinite. He pointed out that the transition from well-crystallized to poorly crystallized kaolinite is shown by a broadening and weakening of the reflections and a tendency for adjacent reflections to fuse into one. A high area/height ratio of the $7 \AA$ peak was taken as indicative of poorly crystallized kaolinite and/or finely crystalline kaolinite. The lack of clearly discernible kaolinite "doublets" (spacings of $4.17 \AA$ and $4.12 \AA$ ) or "Iriplets" (spacings of $2.55 \AA, 2.52 \AA$, and $2.49 \AA ; 2.37 \AA, 2.33 \AA$, and $2.28 \AA$ ) was taken as indicative of poorly crystallized material. 
Chlorite. Chloritic clay minerals may be confused with the kaolinite minerals because many of the diffraction peaks of these two groups coincide. The first- and third-order chlorite reflections ( $14 \AA$ and $4.7 \AA$ respectively) will serve to indicate the presence of chlorite. However, the iron-rich chlorites frequently give only weak first- and third-order reflections. In such cases it is often necessary to conduct further tests. Kaolinite, heated to $600^{\circ} \mathrm{C}$, tends to lose its crystalline character, whereas well-crystallized chlorite is only partially dehydrated at this temperature, causing increased intensity of the $14 \AA$ reflection (op. cit., p. 87). Treatment with warm, dilute $\mathrm{HCl}$ can also be used to take advantage of the greater solubility of chlorite in this acid.

If a $14 \AA$ peak did not develop after heating samples to $600^{\circ} \mathrm{C}$, chlorite was considered to be an unimportant constituent and the $7 \AA$ peak attributed principally to kaolinite. This interpretation was often supported by the presence of a distinct (003) reflection at $2.39 \AA$ and by the presence of a $7 \AA$ peak after treatment with warm dilute $\mathrm{HCl}$.

Illite. The group name illite is used here for the clay minerals exhibiting an integral sequence of basal reflections at approximately $10 \AA, 5 \AA$ and $3.3 \AA$. The $10 \AA$ peak is typically asymmetrical toward the low angle region and the $3.3 \AA$ peak is asymmetrical toward the high angle region. The lack of symmetry is taken as an indication of small particle size, variation in the interlayer cation and/or occasional slight interlayer hydration (op. cit. p. 67 and BRADLEY, 1954).

No attempt has been made to distinguish the polymorphic forms of illite in the complex mixtures which characterize the Danish Paleogene.

Montmorillonite. The montmorillonite group of minerals was identified by (001) peaks at approximately 12 to $15 \AA$ (untreated sample), $17 \AA$ (glycolated sample) and $10 \AA$ (heated sample). The c-axis dimension of montmorillonite is not fixed but varies with the type of exchangeable cation occurring between the silicate layers and the thickness of the polar molecules occurring between the silicate layers. Under ordinary conditions a montmorillonite with $\mathrm{Na}^{+}$as the exchangeable ion frequently has one interlayer of molecular water and a c-axis spacing of $12.5 \AA$; with $\mathrm{Ca}^{++}$ there are frequently two molecular water layers and a c-axis spacing of about $15.5 \AA$ (Grim, 1953, p. 57). Ethylene glycol expands the lattice of montmorillonite to $17 \AA$ (op. cit., p. 93) and heating to $250^{\circ} \mathrm{C}$ decreases the lattice spacing to approximately $10 \AA$ A.

Mixed-layer clay minerals. Brown and MacEwan (1951, p. 266) have recognized three types of mixed-layer clay minerals: regularly interstratified clay minerals, randomly interstratified clay minerals, and segregated mixed-layer clay minerals.

The regularly interstratified mixed-layer clay minerals exhibit "superlattice" characteristics. They give a high (001) spacing and a regular series of sharp higher order reflections with spacings which are submultiples of the (001) spacing. The high (001) spacing represents a composite of the (001) spacings of the interstratified clay minerals. Regularly interstratified mixed-layer clay minerals were not detected in the samples studied.

If the mixture is a random interstratification of layer clay minerals, a nonintegral 
series of reflections is obtained from the basal planes. The reflections occur at positions where the reflections from the components nearly coincide, and they vary in intensity, shape and position, according to the relative proportion of the constituents in the mixed-layer structure. Randomly interstratified clay minerals were found mainly in the samples from the Sövind Marl.

The segregated mixed-layer clay minerals are characterized by a varying proportion of cation density within individual crystallites and from crystallite to crystallite. The diffraction peak of the major clay mineral is generally simply altered in shape and intensity by the development of secondary layers of different composition within the crystallite of the major mineral. Brown and MACEwan (op. cit., p. 267) stated that segregated mixed-layer clay minerals may be composed of a clay mineral in various states of hydration. The illite structure is often partially "degraded" by interlayer hydration. If the layers collapse with heating or expand with ethylene glycol treatment, they may be called montmorillonitic (BradLey, 1954, p. 332). Minor amounts of segregated mixed-layer clay minerals were identified in the samples studied.

\section{Semi-quantitative Analysis.}

The relative abundance of clay minerals present in the samples was determined by the methods outlined by Johns, Grim and Bradley (1954) and Schultz (1960). These methods have several limitations, but are relatively simple and rapid and give a clearer indication of the distribution of the clay minerals in a large group of samples than could otherwise be obtained.

The peak intensities of the major clay components were measured from the diffractometer traces of the glycolated samples. The peaks in the $17 \AA$ to $7 \AA$ range were used in order to obtain comparisons at comparable diffractometer angles and in order to minimize operating errors in measuring peak intensities. The relative abundance of the clay minerals was recorded as parts in ten of the less than two micron fraction.

Illite was used as a common denominator. All components were compared to the intensity of the $10 \AA$ peak as recorded on the diffractometer traces of the glycolated samples. The integration procedure suggested by Johns, Grim and BradLey (1954, pp. 246-250) was adopted for comparing montmorillonite with illite. The procedure consists of summing the observed intensities from a glycolated sample under the maximum of the $17 \AA$ peak and the intensities $1 / 2^{\circ} 2 \theta$ to each side of the maximum. This sum is then divided by a factor of four and the quotient compared directly with illite.

It was not possible to isolate the reflections of the mixed-layer clay minerals for quantitative analysis. The minerals are montmorillonitic and their relative abundance is necessarily included with montmorillonite in the quantitative analyses. Difficulties of this type are inherent in all work dealing with natural clay mineral mixtures and are caused by overlapping X-ray diffraction peaks from materials with generally similar structural schemes.

The procedure for comparing illite with kaolinite was adopted from that suggested by Schultz (1960). The procedure consists of a direct comparison of the observed intensities under the maximum of the $7 \AA$ peak and the $10 \AA$ peak of the traces 
obtained from the glycolated samples. According to Schultz, the two peaks should be compared directly when the kaolinite is of a low order of crystallinity. The shape of the $7 \AA$ peak, as recorded from the oriented slides, was used to evaluate the crystallinity of the kaolinite, since the critical non-basal peaks could not be discerned. 


\section{Mineralogical Data}

\section{General Statement.}

Clay mineral data obtained from the samples studied are presented in the following paragraphs. The semi-quantitative analyses are summarized in tables 2 to 9 and the average clay mineral composition is shown in figure 10 . Representative diffractometer traces are shown in figures 3 to 9 .

\section{Lellinge Greensand.}

Montmorillonite, illite and mixed-layer clay minerals are present in the Lellinge Greensand. Montmorillonite is the dominant clay mineral in the samples studied. The (001) reflection of the untreated sample occurs in the 13.4 to $14.5 \AA$ range, and the lattice expands to $17 \AA$ after treatment with ethylene glycol and collapses to $10 \AA$ after heating to $250^{\circ} \mathrm{C}$.

The $10 \AA$ and $17 \AA$ diffraction peaks recorded from the X-ray analysis of several samples have shapes and intensities which indicate the presence of segregated mixed-layer minerals. The $10 \AA$ reflection is sharpened after heating and glycolation, indicating that the segregated mixed-layer mineral is montmorillonitic. It was not possible to isolate the reflection of the montmorillonitic segregated mixed-layer clay mineral for quantitative analysis. It is, however, possible to evaluate the total amount of expansible material present in the sample by comparing the change in intensity of the $10 \AA$ peak before and after heat treatment. The total amount of expansible material thus calculated can be compared with the amount calculated for montmorillonite and the difference attributed to the expansible mixed-layer clay. The results of this procedure indicate that only trace amounts of mixed-layer clays are present.

The clay minerals are often poorly crystallized and in such cases only qualitative analysis is possible. Illite is present in only minor amounts and frequently the illite structure is partially degraded. Only minor amounts of $\mathrm{K}^{+}$fixation were noted and $\mathrm{Mg}^{++}$treatment produced no noticeable effect on the clay minerals.

Microscopic examination of the bulk sample indicates that glauconite pellets are present in the Lellinge Greensand. The term "glauconite" is currently being used with a dual connotation and may refer to either a greenish, micaceous mineral or to small, spherical, green, earthy pellets (BuRst, 1958, p. 310). In the present work the word "glauconite" is used as a morphologic term to describe greenish pellets in general. The pellets occur as cavity fillings in foraminifera tests and as small isolated pellets. They are generally less than $0.5 \mathrm{~mm}$ in diameter.

It was not possible to isolate the pellets in the samples studied. However, some samples are very glauconitic and it is likely that the diffractometer traces reflect the 

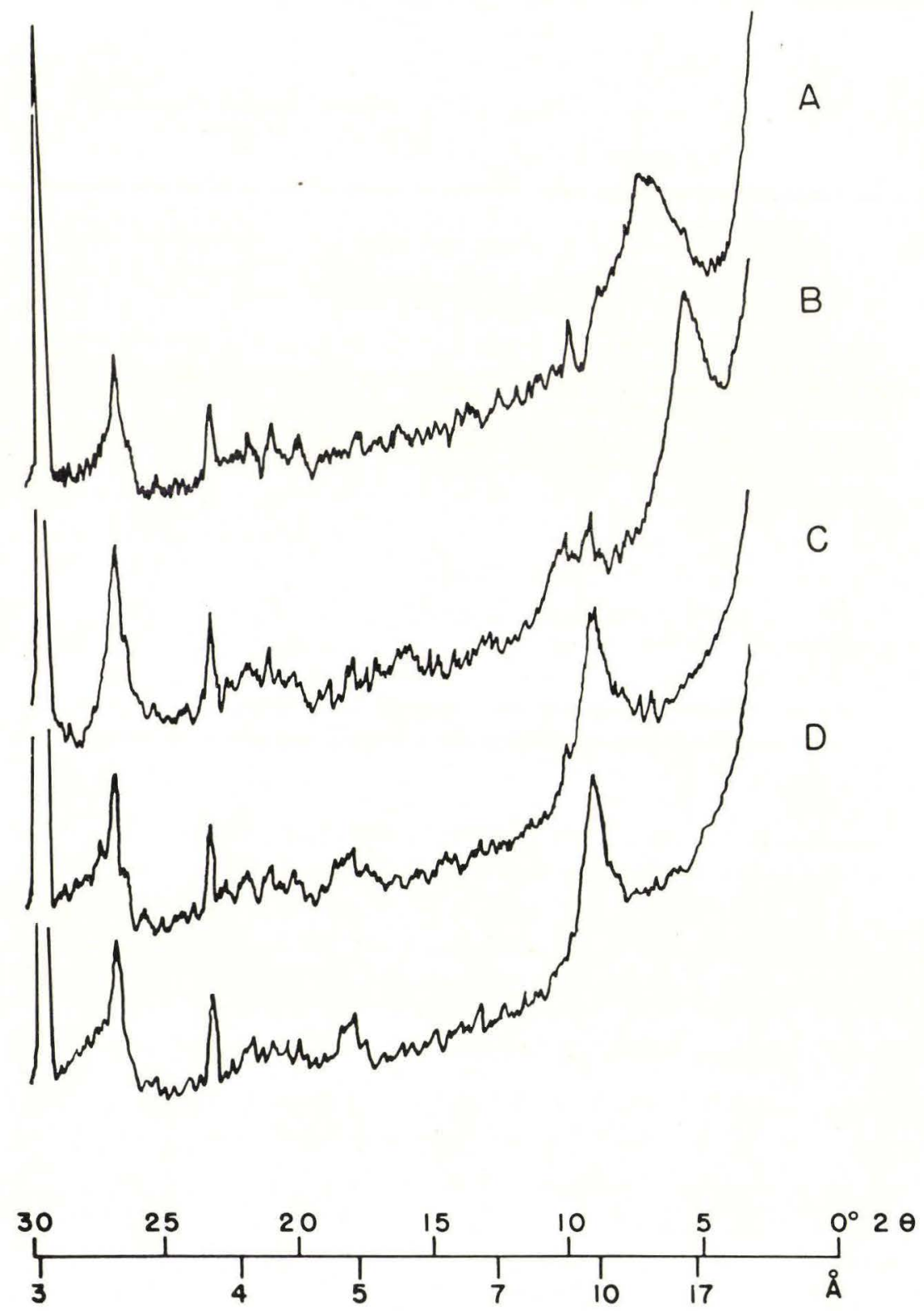

Figure 3. Diffractometer traces made on an XRD-5 General Electric logarithmic recording diffractometer using copper radiation.

Lellinge Greensand: Lellinge, Zealand (sample number 12304-6051). Oriented specimens of the $<2 \mu$ clay fraction. (A) Sample air-dried. (B) Sample treated with ethylene glycol. (C) Sample heated to $250^{\circ} \mathrm{C}$. (D) Sample heated to $450^{\circ} \mathrm{C}$. 
Table 2. Summary of clay mineral composition of Lellinge Greensand*

\begin{tabular}{l|c|c|c|c}
\hline Sample No. & Kaolinite & Illite & $\begin{array}{c}\text { Mixed-layer } \\
\text { clay minerals }\end{array}$ & $\begin{array}{c}\text { Montmor- } \\
\text { illonite }\end{array}$ \\
\hline $12301-6021$ & $\mathrm{X}$ & $\mathrm{M}(\mathrm{d})$ & $\mathrm{T}$ & $\mathrm{A}$ \\
$12302-6087$ & $\mathrm{X}$ & $\mathrm{M}(\mathrm{d})$ & $\mathrm{T}$ & $\mathrm{A}$ \\
$12303-6178$ & $\mathrm{X}$ & 4 (d) & $\mathrm{T}$ & $6^{-}$ \\
$12304-6051$ & $\mathrm{X}$ & 3 & $\mathrm{X}$ & 7 \\
$12306-6203$ & $\mathrm{X}$ & 3 & $\mathrm{X}$ & $7^{-}$ \\
$12305-6073$ & $\mathrm{X}$ & 3 (d) & $\mathrm{T}$ & $5^{-}$ \\
12313 & $\mathrm{X}$ & 5 (d) & $\mathrm{T}$ & \\
\hline
\end{tabular}

* The relative abundance of the clay minerals is expressed in parts in ten of the $<2 \mu$ fraction. Only qualitative evaluations are given for the clay minerals which are poorly crystallized or present in minor or trace amounts.
A - abundant
M - moderately abundant
$\mathrm{T}$ - present in minor or trace amounts
$\mathrm{X}$ - absent
(d) - partially degraded

mineralogy of the pellets without significant amounts of contamination from the non-pellet clay material. The pellets consist of a heterogeneous mixture of "degraded" illite, montmorillonite, and segregated mixed-layer clay minerals. It would be necessary to combine X-ray diffraction data and chemical analyses of uncontaminated pellets in order to determine the mineralogical composition of the pellets with greater precision.

\section{Kerteminde Clay.}

The Kerteminde Clay is characterized by a high montmorillonite content and the absence of kaolinite. Illite is also present. Montmorillonite is the dominant clay mineral present and is more abundant in the Kerteminde Clay than in the under-

Table 3. Summary of clay mineral composition of Kerteminde Clay*

\begin{tabular}{c|c|c|c}
\hline Sample No. & Kaolinite & Illite & $\begin{array}{c}\text { Montmor- } \\
\text { illonite }\end{array}$ \\
\hline K-3b & X & 2 & 8 \\
K-3a & X & 2 & 8 \\
K-2b & X & 1 & 9 \\
K-2a & X & 1 & 9 \\
K-1b & X & T & $10^{-}$ \\
K-1a & X & T & $10^{-}$ \\
\hline
\end{tabular}

* The relative abundance of the clay minerals is expressed in parts in ten of the $<2 \mu$ fraction. Only qualitative evaluations are given for the clay minerals present in trace amounts.

$\mathrm{T}-$ present in minor or trace amounts

$\mathrm{X}$ - absent 

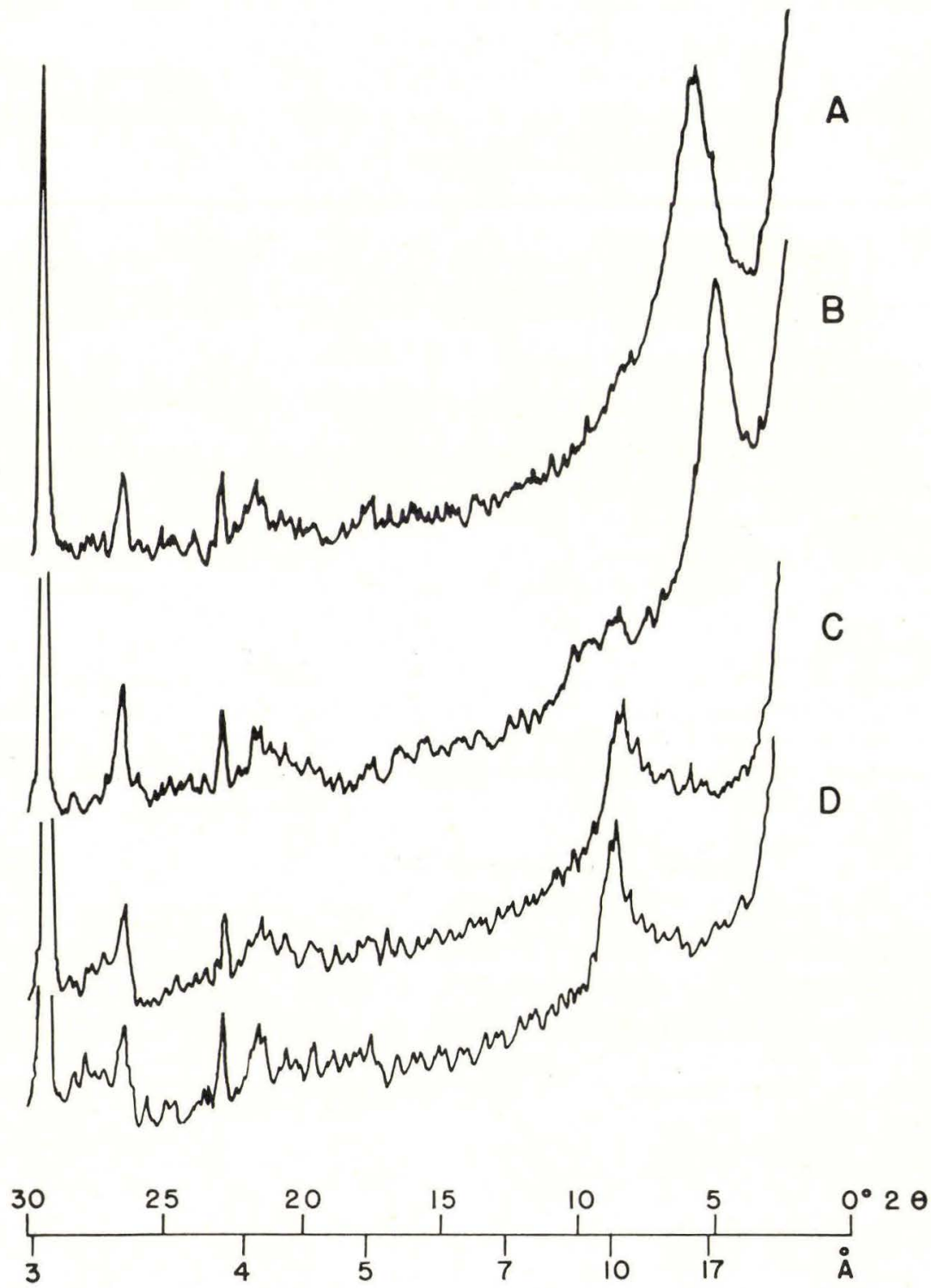

Figure 4. Diffractometer traces made on an XRD-5 General Electric logarithmic recording diffractometer using copper radiation.

Kerteminde Clay: Lundsgaard Klint, Funen (sample number K-2b). Oriented specimens of the $<2 \mu$ clay fraction. (A) Sample air dried. (B) Sample treated with ethylene glycol. (C) Sample heated to $250^{\circ} \mathrm{C}$. (D) Sample heated to $450^{\circ} \mathrm{C}$. 
lying Lellinge Greensand. The (001) reflection of the untreated samples occurs in the 14.5-15.2 $\AA$ range, indicating the presence of $\mathrm{Ca}^{++}$as the exchangeable ion. The first-order montmorillonite reflection of the glycolated sample occurs at approximately $17 \AA$ and at approximately $10 \AA$ after the sample has been heated to $250^{\circ} \mathrm{C}$.

Illite is present in only minor amounts and the diagnostic reflections are often poorly developed. The (003) reflection is symmetrical indicating little, if any, degradation of the illite structure. The (005) reflection is very weak.

Saturation of the samples of the Kerteminde Clay with potassium and magnesium salts produced no significant effect on the clay minerals.

\section{Mo Clay Formation.}

Eight samples of argillaceous diatomite from both the upper and lower divisions of the Mo Clay Formation were examined by X-ray diffraction techniques. The diffractometer traces from these samples show broad bands beginning at approximately $4.4 \AA$ indicating that the material present is predominantly amorphous. The amorphous material probably reflects the abundance of opaline diatom tests and lesser amounts of volcanic glass. Minor amounts of montmorillonite, illite and quartz are also present.

UNmack (1949, p. 194) studied seven samples of the "clayey diatomites" from the Mo Clay Formation by X-ray techniques. She reported the presence of quartz and montmorillonite in six samples and quartz, montmorillonite and kaolinite in one sample. She reported the (001) reflection for the untreated montmorillonite at $13 \AA$ which indicates the presence of $\mathrm{Na}^{+}$as the exchangeable cation. The montmorillonite lattice expanded to $17.8 \AA$ after treatment with glycerol.

\section{Rösnaes Clay.}

All of the analyzed samples of the Rösnaes Clay contain montmorillonite, illite and kaolinite. Montmorillonite is the dominant clay mineral in the samples studied but is present in significantly lesser amounts than in the Paleocene samples. The (001) reflection of the untreated sample occurs in the 11.77 to $12.50 \AA$ range indicating the presence of $\mathrm{Na}^{+}$as the exchangeable ion. The lattice expands to approximately $17 \AA$ after glycolation and collapses to approximately $10 \AA$ after heating to $250^{\circ} \mathrm{C}$.

Kaolinite is present in moderate amounts. The $7 \AA$ peak is not affected by treatment of the sample with warm, dilute $\mathrm{HCl}$ but is appreciably diminished when the sample is heated to $450^{\circ} \mathrm{C}$. Kaolinite "doublets" and "triplets" were not discernable and the height/area ratio of the $7 \AA$ peak indicated that the kaolinite is not wellcrystallized.

The (001) reflection of illite is represented by a weak "shoulder" on the high angle side of the montmorillonite peak in the untreated sample, but the third-order reflection of illite is well developed and slightly asymmetrical to the high angle side. The (001) and (003) illite peaks are sharp and symmetrical after glycolation. The $10 \AA$ peak is slightly increased in intensity at the expense of the (001) peak for montmorillonite after $\mathrm{K}^{+}$saturation. The change in intensity of the $10 \AA$ peak may 

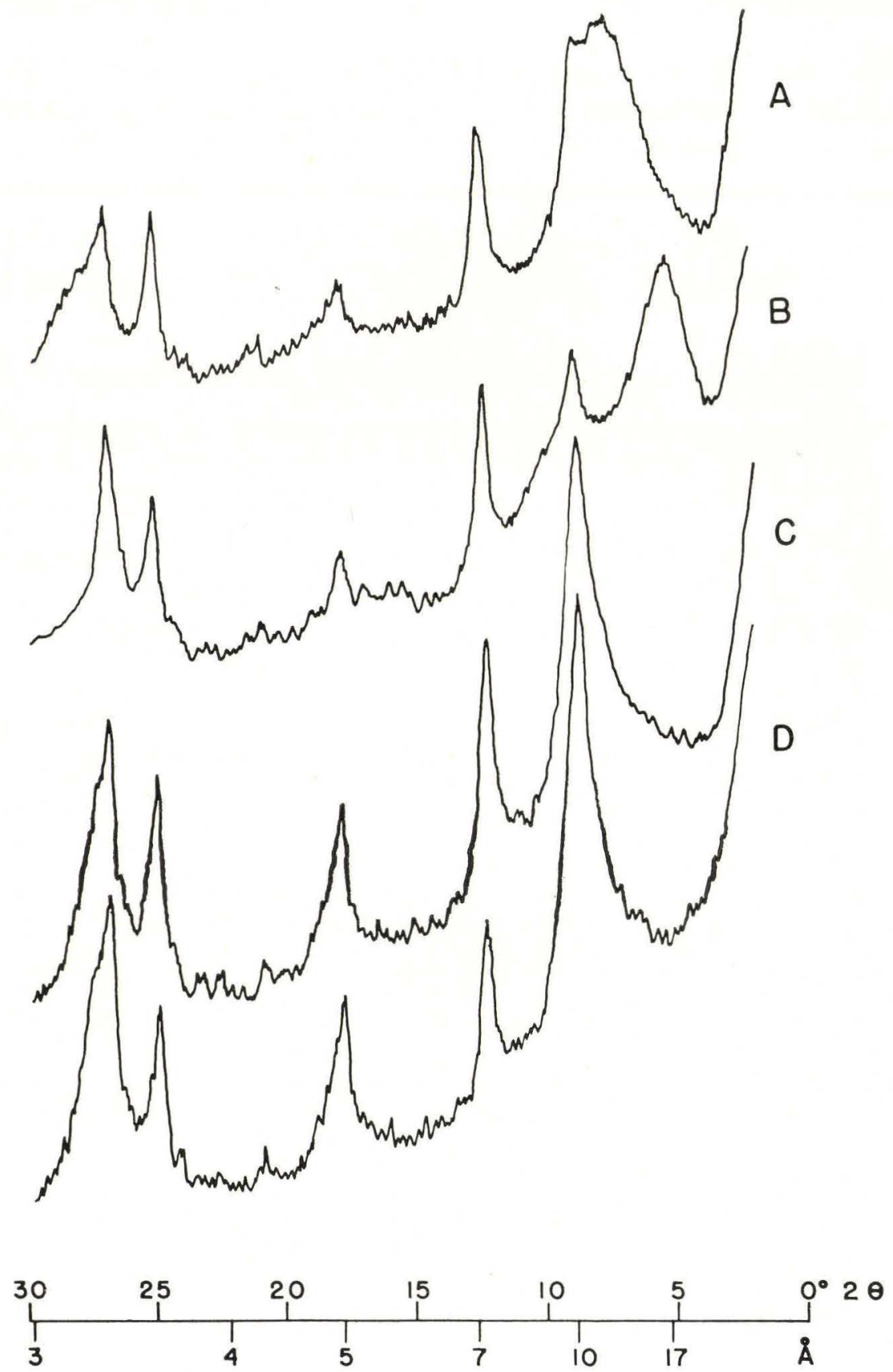

Figure 5. Diffractometer traces made on an XRD-5 General Electric logarithmic recording diffractometer using copper radiation.

Rösnaes Clay: Rösnaes, Zealand (sample number RC-2a). Oriented specimens of the $<2 \mu$ clay fraction. (A) Sample air-dried. (B) Sample treated with ethylene glycol. (C) Sample heated to $250^{\circ} \mathrm{C}$. (D) Sample heated to $450^{\circ} \mathrm{C}$. 
Table 4. Summary of clay mineral composition of Mo Clay*

\begin{tabular}{|c|c|c|c|c|}
\hline Sample No. & Kaolinite & Illite & $\begin{array}{c}\text { Montmor- } \\
\text { illonite }\end{array}$ & Remarks \\
\hline $\mathrm{MF}-4$ & $\mathrm{X}$ & $\mathrm{x}$ & $?$ & Predominantly amorphous \\
\hline MF-3 & $\mathrm{X}$ & $\mathrm{x}$ & $\mathrm{M}(?)$ & $\begin{array}{c}\text { Predominantly amorphous } \\
\text { material }\end{array}$ \\
\hline MF-2 & $\mathrm{x}$ & $\mathrm{x}$ & M & $\begin{array}{c}\text { Predominantly amorphous } \\
\text { material }\end{array}$ \\
\hline MF-1 & $\mathrm{X}$ & $\mathrm{X}$ & M & $\begin{array}{c}\text { Predominantly amorphous } \\
\text { material }\end{array}$ \\
\hline $\mathrm{MH}-7$ & $\mathrm{x}$ & $\mathrm{x}$ & $\mathrm{x}$ & $\begin{array}{c}\text { Predominantly amorphous } \\
\text { material }\end{array}$ \\
\hline $\mathrm{MH}-5$ & $\mathrm{x}$ & $\mathrm{x}$ & $\mathrm{x}$ & $\begin{array}{c}\text { Predominantly amorphous } \\
\text { material }\end{array}$ \\
\hline MH-3 & $\mathrm{X}$ & $\mathrm{x}$ & $?$ & $\begin{array}{c}\text { Predominantly amorphous } \\
\text { material }\end{array}$ \\
\hline $\mathrm{MH}-1$ & $\mathrm{X}$ & 2 & 8 & With amorphous material \\
\hline
\end{tabular}

* The relative abundance of the clay minerals is expressed in parts in ten of the $<2 \mu$ fraction. Only qualitative evaluations are given for the clay minerals which are poorly crystallized or present in minor or trace amounts.

$$
\begin{aligned}
& \mathrm{M} \text { - moderately abundant } \\
& \mathrm{X} \text { - absent }
\end{aligned}
$$

Table 5. Summary of clay mineral composition of Rösnaes Clay*

\begin{tabular}{l|c|c|c}
\hline Sample No. & Kaolinite & Illite & Montmorillonite \\
\hline RC-2b & 3 & 2 & 5 \\
RC-2a & 2 & 4 & 4 \\
RC-1b & 4 & 2 & 4 \\
RC-1a & 3 & 2 & 5 \\
RL-1b-1 & 2 & 4 & 4 \\
RL-1b-2 & 1 & 4 & 5 \\
RL-1a & 2 & 4 & 4 \\
\hline
\end{tabular}

The relative abundance of the clay minerals is expressed in parts in ten of the $<2 \mu$ fraction.

indicate that minor amounts of "degraded" illite are present, or it may indicate minor $\mathrm{K}^{+}$fixation in the montmorillonite lattice. The clay minerals are not significantly affected by mild $\mathrm{Mg}^{++}$treatment.

\section{Lillebelt Clay.}

The mineral composition of the Lillebelt Clay is similar to that of the Rösnaes Clay. Montmorillonite is the dominant clay mineral in both formations but the kaolinite-illite ratio is reversed. Mild $\mathrm{K}^{+}$and $\mathrm{Mg}^{++}$treatment had no significant effect on the clay minerals. 


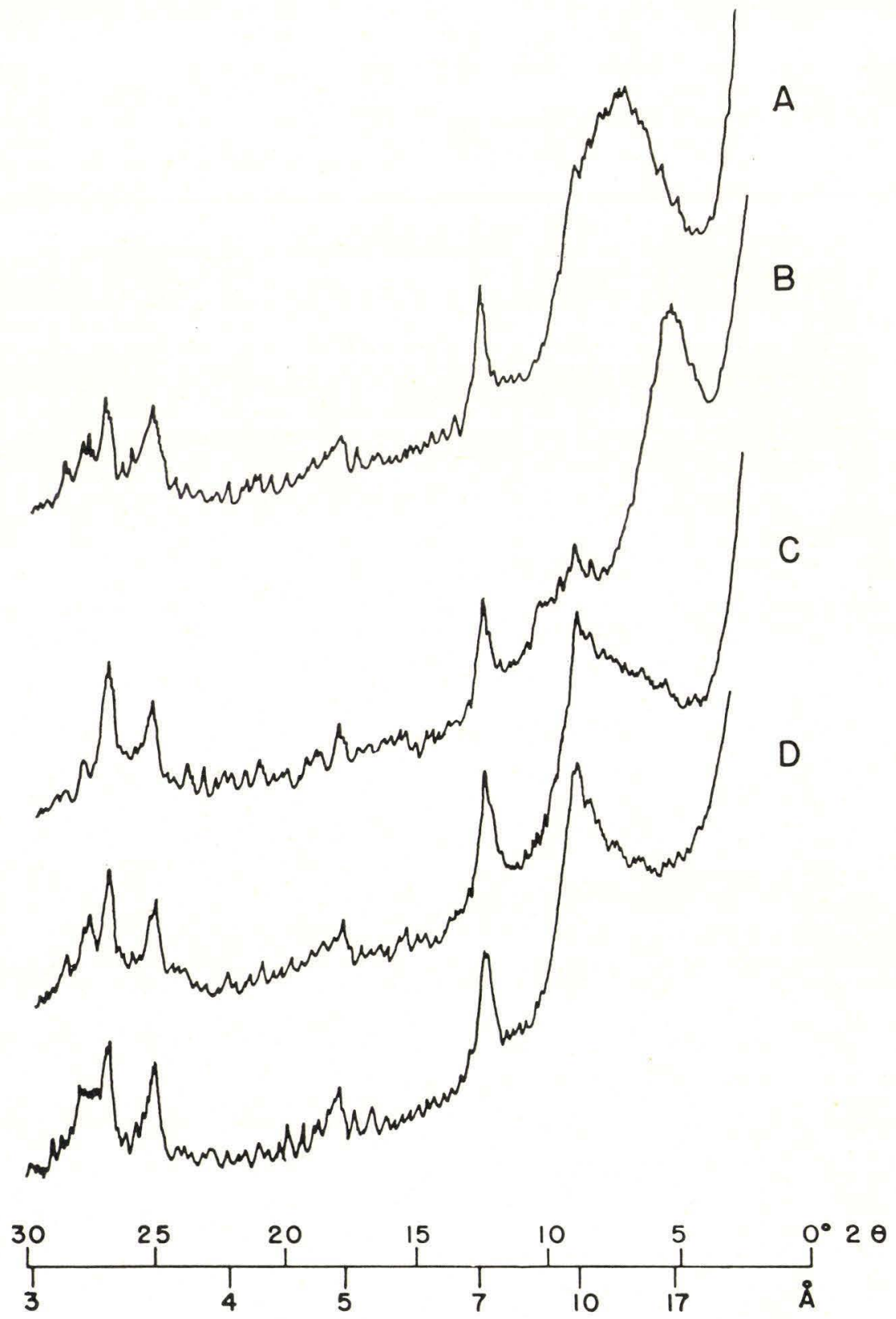

Figure 6. Diffractometer traces made on an XRD-5 General Electric logarithmic recording diffractometer using copper radiation.

Lillebelt Clay: Boring at Lille Elsted, Jutland (sample number 79.174, 50-51 meters). Oriented specimens of the $<2 \mu$ clay fraction. (A) Sample air-dried. (B) Sample treated with ethylene glycol. (C) Sample heated to $250^{\circ} \mathrm{C}$. (D) Sample heated to $450^{\circ} \mathrm{C}$. 
Table 6. Summary of clay mineral composition of Lillebelt Clay*

\begin{tabular}{|c|c|c|c|}
\hline Sample No. & Kaolinite & Illite & Montmorillonite \\
\hline $\begin{array}{l}79.174-41 \text { to } 42 \mathrm{~m} . \\
79.174-42 \text { to } 43 \mathrm{~m} . \\
79.174-43 \text { to } 44 \mathrm{~m} . \\
79.174-44 \text { to } 45 \mathrm{~m} . \\
79.174-45 \text { to } 46 \mathrm{~m} \text {. } \\
79.174-46 \text { to } 47 \mathrm{~m} . \\
79.174-47 \text { to } 48 \mathrm{~m} . \\
79.174-48 \text { to } 49 \mathrm{~m} . \\
79.174-49 \text { to } 50 \mathrm{~m} . \\
79.174-50 \text { to } 51 \mathrm{~m} . \\
79.174-51 \text { to } 52 \mathrm{~m} . \\
79.174-52 \text { to } 53 \mathrm{~m} .\end{array}$ & $\begin{array}{l}4 \\
3 \\
4 \\
3 \\
2 \\
4 \\
3 \\
3 \\
3 \\
3 \\
3 \\
3\end{array}$ & $\begin{array}{l}1 \\
2 \\
1 \\
2 \\
2 \\
1 \\
2 \\
2 \\
1 \\
1 \\
1 \\
1\end{array}$ & $\begin{array}{l}5 \\
5 \\
5 \\
5 \\
6 \\
5 \\
5 \\
5 \\
6 \\
6 \\
6 \\
6\end{array}$ \\
\hline
\end{tabular}

* The relative abundance of the clay minerals is expressed in parts in ten of the $<2 \mu$ fraction.

Graff-Petersen (1955, p. 7) detected chlorite in the Lillebelt Clay samples which were recovered from borings in the Little Belt near Rögle Klint.

\section{Sövind Marl.}

The Sövind Marl is characterized by a high montmorillonite content and minor amounts of illite, mixed-layer clays and poorly crystallized kaolinite.

Montmorillonite is the dominant clay mineral present in the samples studied but the montmorillonite content does not vary appreciably from the montmorillonite content of the Lillebelt Clay. The (001) reflection of the untreated sample occurs in the 12.6 to $14.7 \AA$ range and the lattice expands to approximately $17 \AA$ when the sample is treated with ethylene glycol. Heat treatment causes the lattice to collapse to $10 \AA$.

Table 7. Summary of clay mineral composition of Sövind Marl*

\begin{tabular}{|c|c|c|c|c|}
\hline Sample No. & Kaolinite & Illite & $\begin{array}{l}\text { Montmor- } \\
\text { illonite }\end{array}$ & $\begin{array}{l}\text { Mixed-layer } \\
\text { clay minerals }\end{array}$ \\
\hline $\begin{array}{l}79.174-16 \mathrm{~m} . \\
79.174-22 \mathrm{~m} . \\
79.174-24 \mathrm{~m} . \\
79.174-27 \mathrm{~m} . \\
79.174-28 \mathrm{~m} . \\
79.174-28 \text { to } 29 \mathrm{~m} \text {. } \\
79.174-29 \text { to } 30 \mathrm{~m} \text {. } \\
79.174-30 \text { to } 31 \mathrm{~m} . \\
79.174-31 \text { to } 32 \mathrm{~m} . \\
79.174-32 \text { to } 33 \mathrm{~m} . \\
79.174-33 \text { to } 34 \mathrm{~m} \text {. } \\
79.174-34 \text { to } 35 \mathrm{~m} .\end{array}$ & $\begin{array}{l}4 \\
4 \\
5 \\
4 \\
4 \\
4 \\
4 \\
4 \\
4 \\
3 \\
4 \\
3\end{array}$ & $\begin{array}{l}1 \\
2 \\
2 \\
2 \\
1 \\
2 \\
1 \\
1 \\
1 \\
1 \\
1 \\
1\end{array}$ & $\begin{array}{l}5 \\
4 \\
3 \\
4 \\
5 \\
4 \\
5 \\
5 \\
\mathrm{X} \\
\mathrm{X} \\
\mathrm{X} \\
\mathrm{X}\end{array}$ & $\begin{array}{l}\mathrm{X} \\
\mathrm{X} \\
\mathrm{X} \\
\mathrm{X} \\
\mathrm{X} \\
\mathrm{X} \\
\mathrm{X} \\
\mathrm{X} \\
5 \\
6 \\
5 \\
6\end{array}$ \\
\hline
\end{tabular}


Table 7. Continued

\begin{tabular}{|c|c|c|c|c|}
\hline Sample No. & Kaolinite & Illite & $\begin{array}{l}\text { Montmor- } \\
\text { illonite }\end{array}$ & $\begin{array}{l}\text { Mixed-layer } \\
\text { clay minerals }\end{array}$ \\
\hline 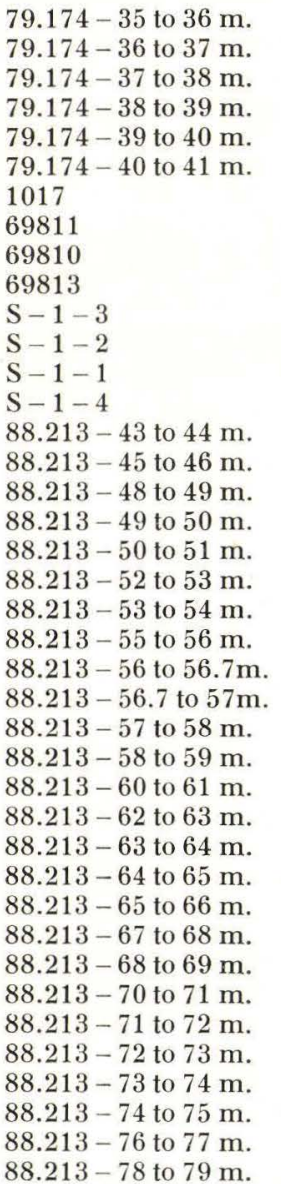 & $\begin{array}{l}4 \\
4 \\
4 \\
4 \\
3 \\
3 \\
3 \\
2 \\
3 \\
3 \\
4 \\
3 \\
3 \\
4 \\
4 \\
3 \\
2 \\
3 \\
3 \\
2 \\
3 \\
3 \\
3 \\
3 \\
3 \\
3 \\
4 \\
4 \\
4 \\
5 \\
4 \\
5 \\
4 \\
4 \\
5 \\
4 \\
4 \\
4 \\
4 \\
4\end{array}$ & $\begin{array}{l}1 \\
1 \\
1 \\
1 \\
1 \\
1 \\
2 \\
3 \\
1 \\
2 \\
2 \\
2 \\
1 \\
2 \\
2 \\
1 \\
2 \\
2 \\
2 \\
2 \\
2 \\
2 \\
2 \\
1 \\
2 \\
2 \\
2 \\
2 \\
2 \\
2 \\
2 \\
2 \\
2 \\
2 \\
2 \\
2 \\
1 \\
2 \\
2 \\
1\end{array}$ & $\begin{array}{l}\mathrm{X} \\
\mathrm{X} \\
\mathrm{X} \\
5 \\
6 \\
6 \\
5 \\
5 \\
6 \\
5 \\
4 \\
5 \\
6 \\
4 \\
4 \\
6 \\
6 \\
5 \\
5 \\
6 \\
\mathrm{X} \\
5 \\
5 \\
6 \\
5 \\
5 \\
4 \\
4 \\
4 \\
3 \\
4 \\
4 \\
3 \\
4 \\
4 \\
4\end{array}$ & $\begin{array}{l}5 \\
5 \\
5 \\
X \\
X \\
X \\
X \\
X \\
X \\
X \\
X \\
X \\
X \\
X \\
X \\
X \\
X \\
X \\
X \\
X \\
5 \\
X \\
X \\
X \\
X \\
X \\
X \\
X \\
X \\
X \\
X \\
X \\
X \\
X \\
X \\
X \\
X \\
X \\
X \\
5\end{array}$ \\
\hline
\end{tabular}

* The relative abundance of the clay minerals is expressed in parts in ten of the $<2 \mu$ fraction.

$\mathrm{X}$ - absent.

Kaolinite and illite are present in lesser amounts and are similar to the kaolinite and illite of the Rösnaes Clay and Lillebelt Clay.

Random mixed-layer clays characterize the lower portion of the Sövind Marl in the boring at Lille Elsted. The random mixed-layer clay mineral is composed of montmorillonite with minor amounts of interstratified illite. The (001) reflection of the untreated samples occurs in the 13.75 to $14.75 \AA$ range and the lattice expansion 


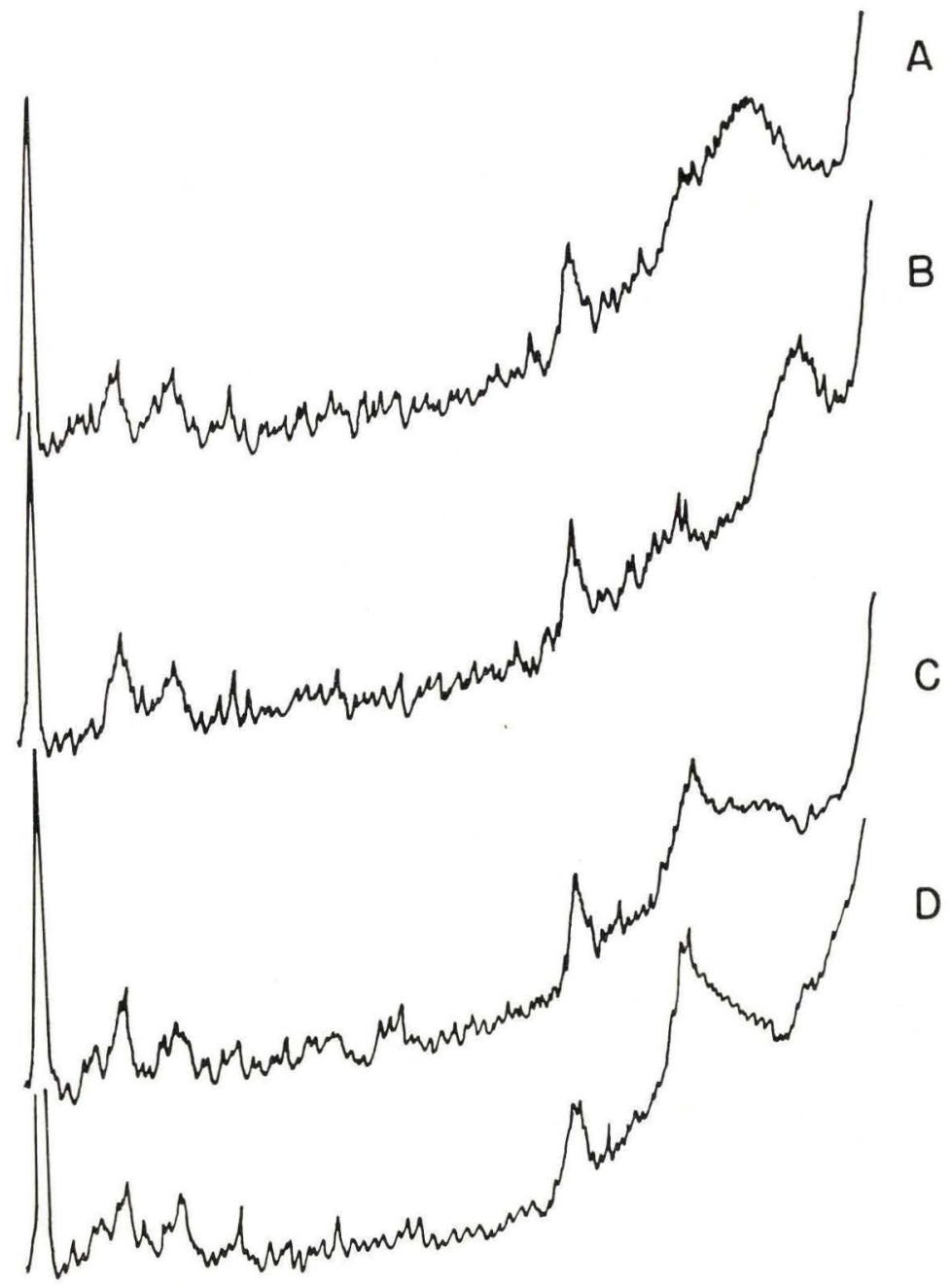

A

$B$

C

$D$

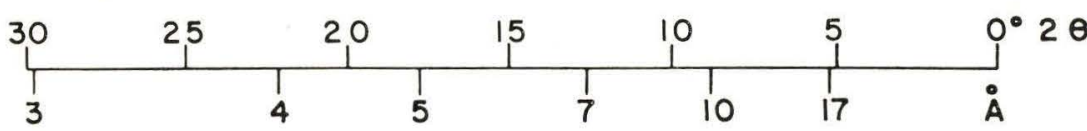

Figure 7. Diffractometer traces made on an XRD-5 General Electric logarithmic recording diffractometer using copper radiation.

Sövind Marl: Boring at Lille Elsted, Jutland (sample number 79.174, 28-29 meters). Oriented specimens of the $<2 \mu$ clay fraction. (A) Sample air-dried. (B) Sample treated with ethylene glycol. (C) Sample heated to $250^{\circ} \mathrm{C}$. (D) Sample heated to $450^{\circ} \mathrm{C}$. 
is limited to less than $16.6 \AA$ when the sample is treated with ethylene glycol. Integral orders were not present. Heat treatment caused the lattice to collapse to approximately $10 \AA$.

Mild $\mathrm{K}^{+}$treatment resulted in minor potassium fixation in the montmorillonite lattice. No significant changes were noted after $\mathrm{Mg}^{++}$saturation.

\section{Septarian Clay.}

The clay mineral assemblage of the Septarian Clay is characterized by the presence of approximately equal amounts of montmorillonite, illite, and poorly crystallized kaolinite. The first-order basal reflection of montmorillonite occurs in the 12.4 to $13.8 \AA$ range, indicating the presence of $\mathrm{Na}^{+}$as the exchangeable ion. The (005) reflection of illite is of moderate intensity, indicating that it is well-crystallized and/or well-oriented. Muscovite was noted in microscopic examination of the bulk sample and it may account in part for the observed intensity of the (005) peak. There was no significant change in the diffractometer traces of the samples which were subjected to mild $\mathrm{K}^{+}$and $\mathrm{Mg}^{++}$treatment.

\section{Upper Oligocene Clays.}

Variable amounts of montmorillonite, illite, and poorly crystallized kaolinite are present in most of the samples of the upper Oligocene clays. The first-order basal reflection of montmorillonite occurs in the 14.47 to $15.25 \AA$ range indicating the presence of $\mathrm{Ca}^{++}$as the exchangeable cation.

The reflection at $45.6^{\circ} 2 \theta$ indicates that the illite present may be well-crystallized and/or well-oriented but the reflection may be partly influenced by minor amounts of muscovite which can be seen in the bulk sample. There was no significant change in the diffractometer traces of the samples which were subjected to mild $\mathrm{K}^{+}$and $\mathrm{Mg}^{++}$treatment.

Table 8. Summary of clay mineral composition Septarian Clay*

\begin{tabular}{|c|c|c|c|}
\hline Sample No. & Kaolinite & Illite & Montmorillonite \\
\hline $\begin{array}{l}88.213-37 \text { to } 38 \mathrm{~m} . \\
88.213-38 \text { to } 39 \mathrm{~m} . \\
88.213-39 \text { to } 40 \mathrm{~m} . \\
88.213-40 \text { to } 41 \mathrm{~m} . \\
88.213-41 \text { to } 42 \mathrm{~m} . \\
\mathrm{S}-3-12 \\
\mathrm{~S}-3-9 \\
\mathrm{~S}-3-6 \\
\mathrm{~S}-3-3 \\
\mathrm{~S}-3-1 \\
\mathrm{UO}-1\end{array}$ & $\begin{array}{l}3 \\
3 \\
2 \\
3 \\
4 \\
3 \\
4 \\
4 \\
3 \\
3 \\
3\end{array}$ & $\begin{array}{l}3 \\
3 \\
3 \\
3 \\
3 \\
3 \\
3 \\
3 \\
3 \\
3 \\
3 \\
3\end{array}$ & $\begin{array}{l}4 \\
4 \\
5 \\
4 \\
3 \\
4 \\
3 \\
3 \\
4 \\
4 \\
4\end{array}$ \\
\hline
\end{tabular}

* The relative abundance of the clay minerals is expressed in parts in ten of the $<2 \mu$ fraction. 

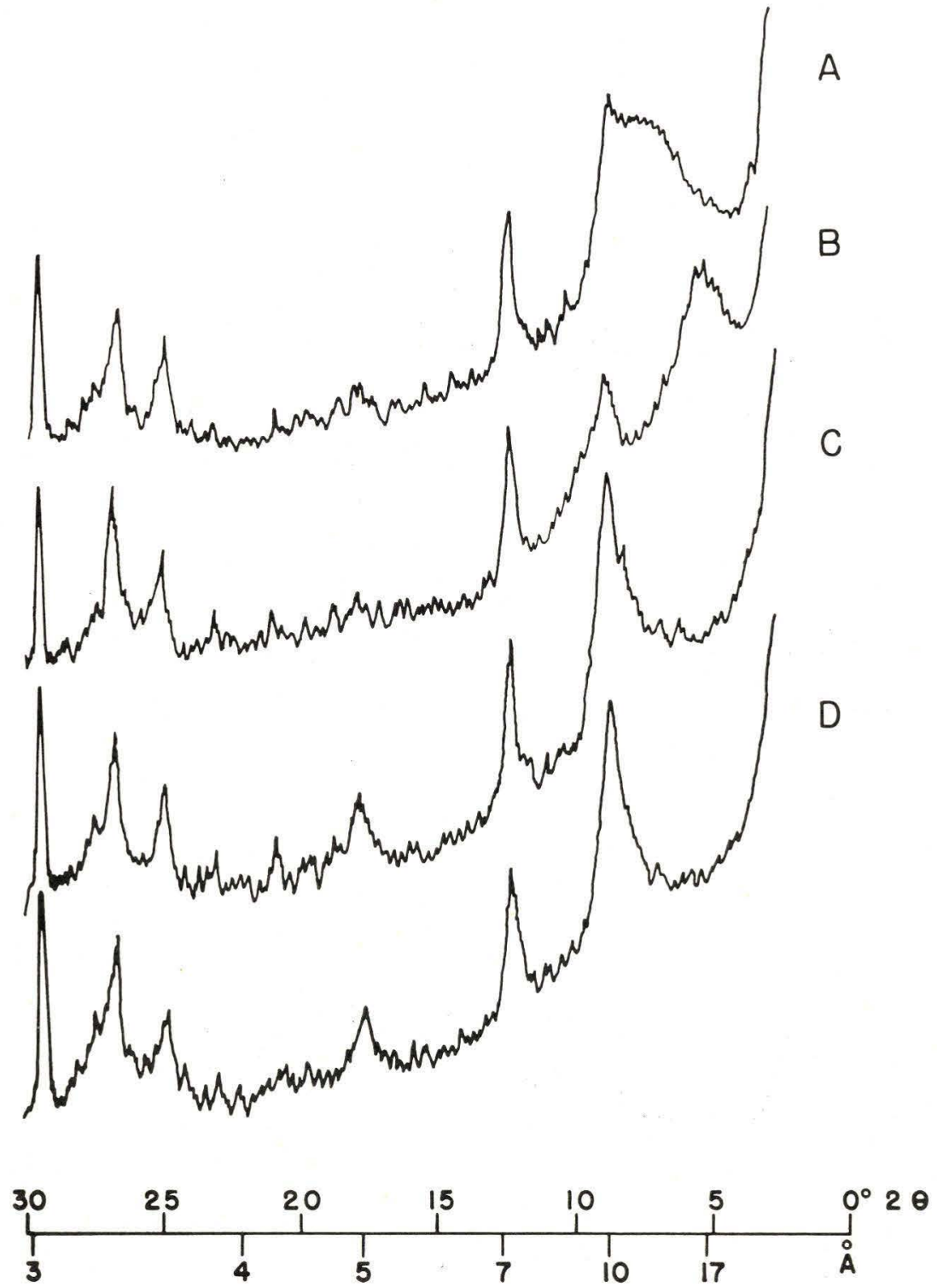

Figure 8. Diffractometer traces made on an XRD-5 General Electric logarithmic recording diffractometer using copper radiation.

Septarian Clay: Ormslev Kvartsvaerk boring, Jutland (sample number 88.213, 40-41 meters). Oriented specimens of the $<2 \mu$ clay fraction. (A) Sample air-dried. (B) Sample treated with ethylene glycol. (C) Sample heated to $250^{\circ}$ C. (D) Sample heated to $450^{\circ} \mathrm{C}$. 


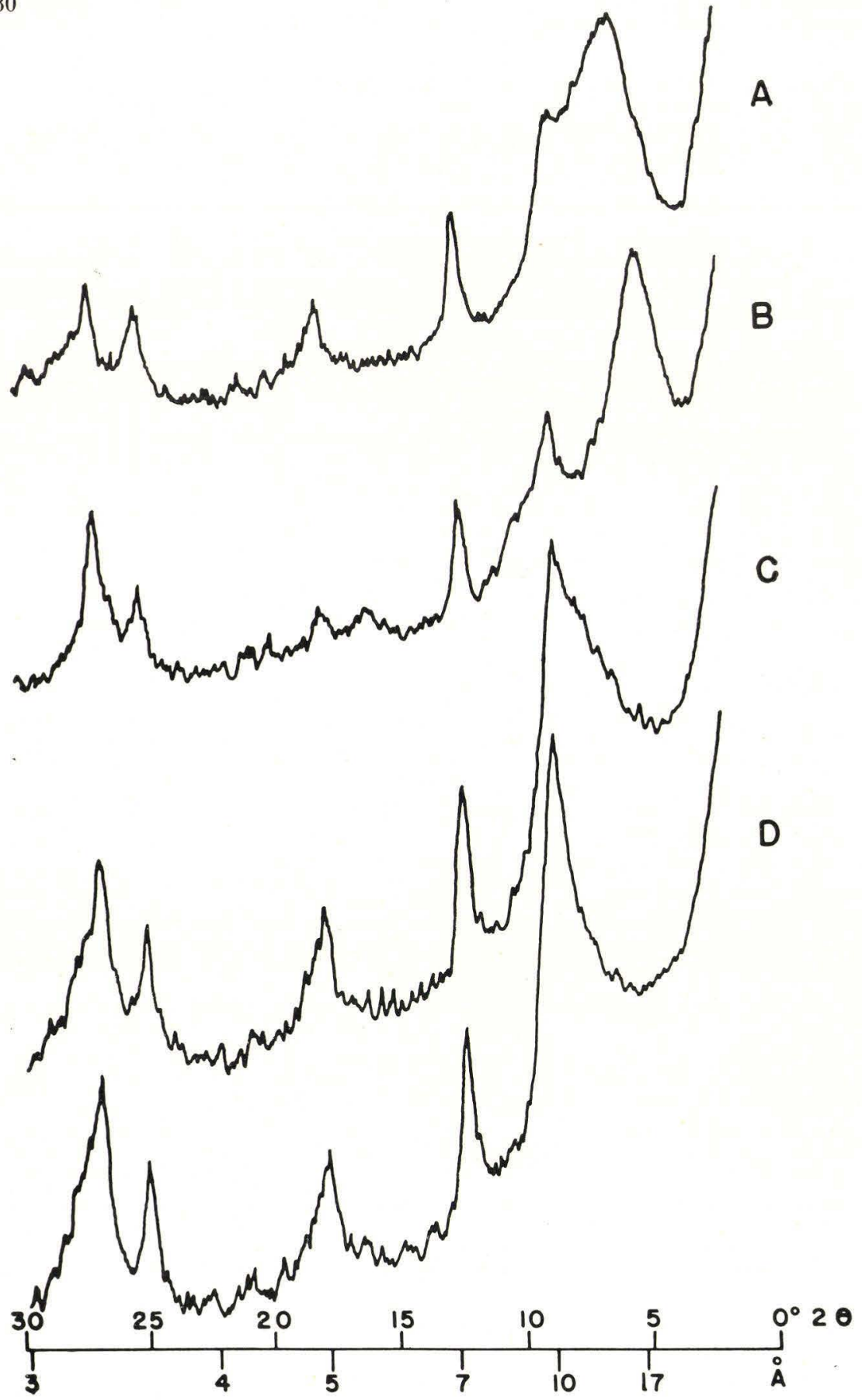

Figure 9. Diffractometer traces made on an XRD-5 General Electric logarithmic recording diffractometer using copper radiation.

Upper Oligocene clay: Ulstrupbro, Jutland (sample number UO-3a). Oriented specimens of the $<2 \mu$ clay fraction. (A) Sample air-dried. (B) Sample treated with ethylene glycol. (C) Sample heated to $250^{\circ} \mathrm{C}$. (D) Sample heated to $450^{\circ} \mathrm{C}$. 
Table 9. Summary of clay mineral composition of Upper Oligocene clays*

\begin{tabular}{c|c|c|c}
\hline Sample No. & Kaolinite & Illite & Montmorillonite \\
\hline UO-3a & 2 & 3 & 5 \\
UO-3b & 2 & 3 & 5 \\
UO-2 & 6 & 4 & X \\
RK-2 & 2 & 4 & 4 \\
RK-1 & 4 & 3 & 3 \\
\hline
\end{tabular}

* The relative abundance of the clay minerals is expressed in parts in ten of the $<2 \mu$ fraction.

$\mathrm{X}$ - absent. 


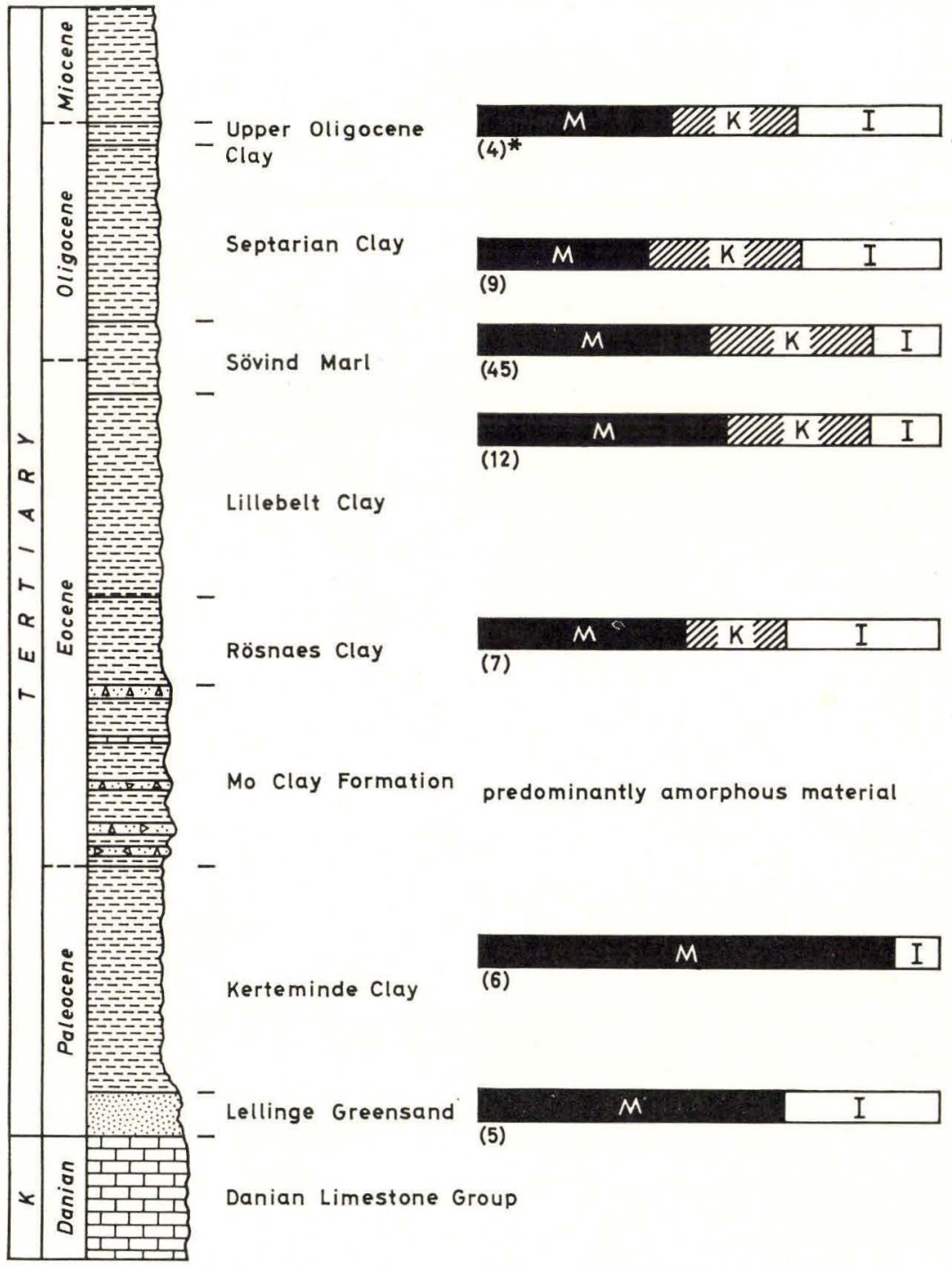

LEGEN D

Lithologies

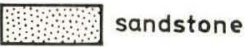

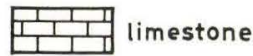

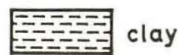

\section{Mineral groups}

$M$ montmorillonite and/or expansible mixed-layer clays Q Kaolinite

I illite

$$
\Delta \Delta \therefore \Delta \text { tuff }
$$

*indicates number of samples analyzed

Figure 10. Lithologies and average clay mineral composition of some Paleogene sediments from Denmark. 


\section{Discussion}

\section{Mineralogical Zonation.}

The occurrence of particular clay minerals or clay mineral suites within rock or time-rock units can be used in refining stratigraphic subdivisions. The Danish Paleogene can be divided into three major zones (referred to as Zones I, II and III) on the basis of the X-ray diffraction data. Zone III can be tentatively divided into four subzones (referred to as Subzones III-A, III-B, III-C, and III-D). Each zone can be recognized by its distinctive mineralogy. Table 10 shows the mineral occurrences which characterize the zones and the differences upon which the zonation is based.

The lowest zone, Zone I, is characterized by a high montmorillonite content, minor or trace amounts of illite and segregated mixed-layer clay minerals and the absence of kaolinite. Only minor amounts of clay minerals are present in the middle

Table 10. Mineralogical zonation of the Danish Paleogene

\begin{tabular}{|c|c|c|c|}
\hline $\begin{array}{l}\text { Mineral } \\
\text { Zones }\end{array}$ & 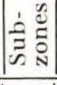 & Characteristic Clay Minerals & Stratigraphic Units \\
\hline \multirow{4}{*}{ Zone III } & D & $\begin{array}{l}\text { Variable amounts of montmorillonite, kao- } \\
\text { linite and illite. }\end{array}$ & $\begin{array}{l}\text { Upper Oligocene clay } \\
\text { Septarian Clay } \\
\text { Upper part of Sövind } \\
\text { Marl }\end{array}$ \\
\hline & C & $\begin{array}{l}\text { Predominantly random mixed-layer mont- } \\
\text { morillonite-illite with lesser amounts of } \\
\text { kaolinite and illite. }\end{array}$ & $\begin{array}{l}\text { Lower part of Sövind } \\
\text { Marl }\end{array}$ \\
\hline & B & $\begin{array}{l}\text { Predominantly montmorillonite with lesser } \\
\text { amounts of kaolinite and illite (illite } \\
\text { less abundant than kaolinite). }\end{array}$ & Lillebelt Clay \\
\hline & A & $\begin{array}{l}\text { Predominantly montmorillonite with lesser } \\
\text { amounts of illite and kaolinite (illite } \\
\text { more abundant than kaolinite). }\end{array}$ & Rösnaes Clay \\
\hline Zone II & & $\begin{array}{l}\text { Predominantly amorphous material with } \\
\text { minor or trace amounts of montmorillonite, } \\
\text { illite, and kaolinite. }\end{array}$ & $\begin{array}{l}\text { Mo Clay Formation } \\
\text { (diatomite beds) }\end{array}$ \\
\hline Zone I & & $\begin{array}{l}\text { Predominantly montmorillonite with minor } \\
\text { or trace amounts of illite and segregated } \\
\text { mixed-layer clay minerals. Absence of kao- } \\
\text { linite is particularly diagnostic. }\end{array}$ & $\begin{array}{l}\text { Kerteminde Marl } \\
\text { Lellinge Greensand }\end{array}$ \\
\hline
\end{tabular}


zone, Zone II, and the zone is characterized by the predominance of amorphous material. Montmorillonite, illite, kaolinite and mixed-layer clay minerals are present in Zone III. The presence of kaolinite distinguishes Zone III from Zone I. Variations in the relative amounts of kaolinite, illite and mixed-layer clay minerals can be used as a basis for tentatively subdividing Zone III. Subzone III-A is distinguished from Subzone III-B by a change in the kaolinite-illite ratio. In Subzone III-B kaolinite is relatively more abundant than illite, whereas in Subzone III-A illite is relatively more abundant. Subzone III-C is characterized by a predominance of mixed-layer clay minerals. Subzone III-D contains variable amounts of montmorillonite, kaolinite and illite.

In some cases the mineralogical zonation shows general parallelism with the lithologic boundaries which have been established by field studies, but there are significant divergences. Subzone III-C, for example, is restricted to the lower portion of the lithologically homogeneous Sövind Marl. The boundaries of Zone I, on the other hand, appear to coincide with the Paleocene Series and Subzone III-D embraces most of the Sövind Marl, the Septarian Clay, and the upper Oligocene clays. The mineralogical zonation thus suggests a framework which may prove useful in interpreting the Paleogene history of the North Sea Basin.

\section{Interpretation.}

The clay mineral assemblage studied could reflect three different general conditions or a combination of the three conditions. These are: (a) the conditions in the source areas, such as degree, intensity and length of time of weathering, plus the nature of the parent material; (b) conditions of changing environment brought about by transportation and depositional history and post-depositional changes; and (c) recent weathering conditions. The present study considers the three general conditions in the interpretation of the clay mineral distribution.

The importance of the source and environmental history in the evolution of the clay minerals is not always easy to evaluate. Many workers have presented evidence supporting environmental change (see esp. Grim, 1958, and Keller, 1956) and there is little doubt that some changes do occur during diagenesis. WEAvEr (1958b), however, presented evidence that clays usually have a detrital origin and that most of their characteristics can be attributed to products of the source area.

The possibility that the clay mineral assemblage results from alterations caused by recent weathering cannot be definitely dismissed. Clay mineral alteration takes place on surface exposures, near moraine-bedrock contacts, and along fractures within generally impermeable clay formations. If significant alteration has taken place, the clay mineral composition of samples collected at or near the surface should be markedly different from those collected from wells below the weathered zone. Well samples were available for the Lillebelt Clay, Sövind Marl and Septarian Clay and no significant differences between the surface and well samples were noted. There is therefore little likelihood that the clay minerals of these samples have been significantly affected by recent weathering. Subsurface control was not available for the Lellinge Greensand, Kerteminde Clay, Rösnaes Clay and upper Oligocene clays, and possible alteration by recent weathering should be kept in mind. 
Zone $I$ is characterized by a high montmorillonite content, minor or trace amounts of illite and segregated mixed-layer clays, and the absence of kaolinite. The abundance of montmorillonite could be related to:

(a) Relatively abundant supply of montmorillonite deposited contemporaneously with the clays and marls;

(b) Diagenesis from other clay material because of the introduction of the necessary cations in marine waters;

(c) Segregation of clay minerals by sorting, preferential floculation, etc.;

(d) Post depositional alteration of other clay material to montmorillonite.

If the montmorillonite is detrital, two possible sources warrant consideration: (1) The abundance of montmorillonite might be attributed to the alteration of volcanic ash and/or erosion of land-deposited volcanic material; (2) the montmorillonite could represent a weathering product of the source land. The region north of the Hercynian massifs experienced intense volcanic activity in the early Tertiary (Eocene?) and the possibility that the high montmorillonite content of Zone I reflects the first stages of volcanism should be considered. There is, however, no evidence of an ash fall in the Paleocene sediments of Denmark nor any evidence for Paleocene ash deposits in the source land and therefore the possibility of a direct volcanic ash origin cannot be proved.

Montmorillonite is a common weathering product. The nature of the source lands is not known but it is possible that the montmorillonite was derived from the metamorphic rocks of the Fennoscandian massif and/or from a carbonate terrain bordering the Fennoscandian massif. The non-clay mineral suite of Zone I reported by GRY (1935, pp. 59-78) does not, however, indicate that the metamorphic rocks of the Fennoscandian massif were an important source area.

GRY (1935, p. 48) regarded much of the calcite of the Lellinge Greensand as a clastic component originating in the disintegration of the Danian carbonates. The clay mineralogy of the Cretaceous carbonates of Denmark has not been studied but UNMACK (1949) and VALETON (1960, p. 32) investigated the clay mineralogy of a thin clay bed ("fish-clay") at the base of the Danian Limestone Group and reported the presence of abundant montmorillonite, calcite, quartz and feldspar. The clay mineralogy of the carbonates associated with the "fish-clay" may be similar. Volcanic tuff layers have been discovered recently in the Maestrichtian stage of northwestern Germany (VALETon, 1959, 1960). Valeton (1960, p. 34) studied the clay mineralogy of the tuff layers and reported the presence of abundant calcium montmorillonite, minor or trace amounts of illite and the absence of kaolinite. This clay mineral suite is similar to that of Zone I. There is, therefore, good evidence that the clay suite is detrital and a product of the carbonate terrain and its associated pyroclastic material.

Ussing (in MADSEN, 1902, pp. 16-21) concluded that the sedimentary evidence indicated that the Paleocene clays were deposited in deep, quiet marine waters. Such an environment, together with slow deposition, would favor diagenetic changes in the clay minerals and the development of montmorillonite and illite. Murray and Harrison (1956, p. 367) suggested that some of the "degraded" clay material carried into the Gulf of Mexico could, during diagenesis, have picked up $\mathrm{Ca}^{++}$or perhaps $\mathrm{Na}^{+}$in the deep portion of the Gulf and thus become diagenetic montmorillonite. Grim and Bradley (1955), and Weaver (1958a) also indicated that some 
clays, previously changed by weathering, may, in the presence of suitable cations, revert to their original types because skeletal structures persist. Griffin and Ingram (1955, p. 199) suggested that the kaolinite being introduced into the Neuse River Estuary of North Carolina might be changed into "chlorite" or illite.

WeAver (1959, p. 182) suggested that segregation of clay mineral suites by sorting is usually more effective than by diagenesis. Montmorillonite occurs as extremely small particles, while illite and kaolinite generally show a larger particle size distribution (Grim, 1953). On the basis of settling velocities alone, montmorillonite would stay in suspension longer and thus be distributed farther from shore. Murray and Harrison (1956, p. 368) noted that montmorillonite is the dominant clay mineral component of the Sigsbee Deep and suggested that its presence could be accounted for by differential suspension and floculation. WhiteHouse and JeFFrey (1955, p. 279) also noted the tendency for preferential floculation of illite and kaolinite relative to montmorillonite. Thus, the high montmorillonite content and lack of significant amounts of other clay minerals in Zone I could be explained by the segregation tendencies of floculation and sorting.

The sediments of Zone I are relatively impermeable and therefore not particularly susceptible to rapid circulation of groundwater; excessive post-depositional change of the clay minerals by ground water is not likely. The samples studied were, however, collected from surface exposures, and possible alteration of the clay structure by weathering cannot be excluded.

Although there are many variables involved, the clay mineral assemblage of Zone I can best be explained as a detrital suite derived from a carbonate terrain bordering the Fennoscandian massif. The high montmorillonite content can be attributed in part to diagenetic changes in the marine environment and/or segregation by preferential floculation or current sorting.

The diatomites and associated tuff beds of Zone II reflect a major change in the geologic events of the Danish portion of the North Sea Basin. BöGGILD (1918, p. 32), Andersen (1937, p. 51) and Norin (1940, p. 37) have demonstrated that a center of volcanism lay in the northern part of the Skagerrak. The tuff is primarily basaltic in composition and extends as far south as northwestern Germany.

The volcanic activity should be reflected in the clay mineral suite of the Mo Clay Formation. Grim (1953, p. 357) and Weaver (1959, p. 171) summarized the literature on the clay minerals associated with volcanic materials. They concluded that volcanic activity, either on a world-wide scale or in restricted areas, is most favorable to the formation of montmorillonite. Volcanic material is also apparently the source for much kaolinite (Ross, Miser, and Stephenson, 1928, p. 186, and Ponder and Keller, 1960, p. 61), illite, and mixed-layer illite-montmorillonite (Ross and Hendricks, 1945, p. 60 and Weaver, 1953, p. 941 and Byström, 1956, p. 45). The results of the X-ray analyses of the diatomites studied by Uммаск (1949) and by the writer are inconclusive. Only minor amounts of clay minerals are present and the bulk of the material is amorphous. Montmorillonite is the dominant clay mineral present and minor amounts of kaolinite and illite can be detected. Droste (1961, p. 1719) reported a similar clay mineral mixture associated with Pleistocene and Recent volcanic material in the saline lake basin sediments of California. The clay minerals present in Zone II undoubtedly are a product of the alteration of volcanic material. 
The greater variety of clay minerals in Zone III reflects the change in source conditions which accompanied the Eocene volcanism. It is also possible that changes in the physical environment account for the variations in the clay mineral assemblage which defines the clay mineral subzones of Zone III. The comparison of the clay minerals of well samples with the surface samples suggests that the clay mineral assemblage of Zone III has not been significantly affected by recent weathering.

The abundance of montmorillonite can be attributed to the alteration of volcanic ash deposited in the sea and/or the erosion of land-deposited volcanic material. There is no reported evidence for an ash fall in the sediments of Zone III but it is not unlikely that some of the volcanic ash associated with the Eocene volcanism of the "North Atlantic Volcanic Province" was carried by the prevailing winds to the Danish portion of the North Sea Basin. There was undoubtedly abundant volcanic material being eroded from the Fennoscandian massif. Illues (1949) and Noriv (1934) suggested that the Skagerrak eruptions and the outpouring of the Scanian basalts were almost contemporaneous. The igneous material is basic and ultrabasic and affords the type of parent material most suited to the formation of montmorillonite (Ross and Hendricks, 1945, p. 64). Illies (1949, p. 39) has shown that the montmorillonite content of the Eocene clays of northwestern Germany decreases southward and disappears south of the Elbe River. The supply of the montmorillonite seems to be clearly related to the volcanic terrain of the Fennoscandian massif.

The presence of kaolinite distinguishes Zone III from Zone I. The kaolinite may also have been formed by the alteration of volcanic ash or by the weathering of the feldspathic material of the Skagerrak volcanics or the Scanian basalts. PONDER and Keller $(1960$, p. 61) concluded that much of the kaolinite associated with the volcanic ash of the Miocene Latah Formation originated from hydrolysis of volcanic ash in freshwater lakes. Inasmuch as there is no direct evidence for a volcanic ash fall associated with the sediments of Zone III it is more likely that the kaolinite represents a weathering product of feldspars. There is abundant feldspathic material associated with the Skagerrak volcanics and the Scanian basalts. The increase in the kaolinite content in the younger sediments of Zone III can be attributed to more mature weathering. The distinction between Subzone III-A and Subzone III-B may therefore have as its basis more thorough weathering of parent material. The mixedlayer montmorillonite-illite clays of Zone III-C may also have originated in the soils of the source land during a period of prolonged weathering.

The variations in clay mineral distribution of Zone III could also be related to the change in physical environment. The increasing amounts of kaolinite and illite might indicate changes in distance from source area, changes in the depth of water or changing current patterns. Varying climate and the chemistry of the marine environment could also be significant factors.

The analysis of the distribution of the clay minerals of the Danish Paleogene thus suggests that the clay mineral occurences can be related to the conditions of the source area with significant modifications brought about by physical and chemical conditions in the environment of deposition. The clay mineral distribution affords a mineralogical framework which can be used in the interpretation of the geological history of the area. A complete interpretation of the history would require regional data in addition to that obtained in the present investigation. 


\section{Conclusions}

The results of this study may be summarized as follows:

(1) Montmorillonite is the dominant clay mineral component of most of the samples investigated. Variable amounts of kaolinite, illite, and mixed-layer clay minerals are present in many of the samples.

(2) Three mineralogical zones can be recognized within the Paleogene interval of Denmark. The zones and their distinguishing characteristics are listed below from oldest to youngest.

(a) Zone I is characterized by a high montmorillonite content, minor or trace amounts of illite and segregated mixed-layer clay minerals, and the absence of kaolinite.

(b) Zone II is characterized by the predominance of amorphous material. Minor amounts of montmorillonite, illite, and kaolinite are present.

(c) Zone III contains variable amounts of montmorillonite, illite, kaolinite and random mixed-layer montmorillonite-illite.

(3) Zone III can be tentatively divided into four subzones on the basis of the variation in the clay mineral distribution.

(4) The clay minerals of Zone III are products of the alteration of the volcanic material of the Fennoscandian massif. Changes in the conditions of the source area and the physical environment of deposition account for the mineralogical variations within this zone.

(5) The clay minerals of Zone II represent alteration products of volcanic ash.

(6) The clay minerals of Zone I are interpreted as a detrital suite originating from the carbonate terrain bordering the Fennoscandian massif. Diagenetic changes in the marine environment and the segregation tendencies of sorting and floculation are considered to be important factors in accounting for the high montmorillonite content of this zone.

(7) The mineralogical data support the concept that the clay minerals are primarily detrital in origin and reflect the composition of the source area. 


\section{Acknowledgements}

The investigation was carried out under the supervision of dr. phil. P. GraffPetersen of the University of Copenhagen and Dr. J. B. Droste of Indiana University; the writer wishes to express his appreciation for their advice and stimulating discussion on various aspects of the investigation. The field work was carried out in co-operation with cand. mag. A. Dinesen of the Geological Survey of Denmark. A. Dinesen also offered much information on recent unpublished investigations of the local stratigraphy.

The writer is grateful to Professor, dr. phil. A. Noe-NygaArd, University of Copenhagen for making available the excellent facilities of the Mineralogical and Geological Institute, and to director, dr. phil. H. Ødum and to dr. phil. Th. SorgenFREI of the Geological Survey of Denmark for kindly furnishing well and surface samples used in the investigation.

Financial support for the investigation was made possible by U.S. Public Law 584, 79th Congress, the Fulbright Act, and by assistantships from Indiana University. Barbara A. TANK assisted the writer in the translation of the foreign literature and in the final preparation of the manuscript. 


\section{Dansk sammendrag}

Nedre tertiær er i Danmark repræsenteret af en karakteristisk, tilsyneladende ret ensartet serie af brogede, fede lerer. En nøjagtigere identificering af de enkelte lag og en korrelation mellem lagene ved hjælp af lermineralogiske undersøgelser synes i høj grad ønskelig, ikke mindst fordi vi i disse sedimenter har en næsten komplet serie af de marine, nedre tertiære aflejringer i Nordsø-bassinet.

I denne afhandling er omtalt en række undersøgelser over lermineral-sammensætningen i udvalgte prøver af lerbjergarter fra det danske paleogen, og resultaternes mineralogiske og stratigrafiske betydning er behandlet.

Lermineralogiske undersøgelser af det danske paleogen er tidligere udfort af Clausen (1932), Unmack $(1944,1949)$ og Graff-Petersen (1955).

\section{Prøvemateriale og unders $\varnothing$ gelses-metodik.}

Lermineralsammensætningen er ved hjælp af röntgendiffraktomeier bestemt på 108 prøver fra det danske paleogen. Prøvematerialet stammer fra følgende lokaliteter, der også er vist i fig. 1:

Lokalitet 1. Lellinge, Sjælland (Lellinge grønsand).

2. København, Sjælland (Lellinge grønsand).

3. Lundsgaard Klint, Fyn (Kerteminde ler).

4. Østerklint, Fur (moler).

5. Hanklit, Mors (moler).

6. Røsnæs, Sjælland (Røsnæs ler).

7. Leca-graven, Hinge, Jylland (Røsnæs ler).

8. Boring ved Lille Elsted, Jylland (DGU ark. nr. 79.174) (Søvind mergel og Lillebælt ler).

9. Røgle Klint, Fyn (oligocæn sandsten og Søvind mergel).

10. Toftum, Jylland (Søvind mergel).

11. Søvind, Jylland (Søvind mergel).

12. Boring ved Ormslev Kvartsværk, Jylland (DGU ark. nr. 88.213) (miocæn? siltsten, septarieler og Søvind mergel).

13. Grundfør Teglværks grav, Jylland (septarieler).

14. Sophienlund Teglværks grav, Ulstrupbro, Jylland (oligocæn ler).

De röntgenografiske undersøgelser er udført dels på Københavns Universitets Mineralogisk-Geologiske Institut, dels på det lermineralogiske laboratorium ved Indiana Universitet, U.S.A. Röntgendiagrammer er optaget på de naturlige prøver, 
og derefter er prøverne glycol-behandlet, opvarmet til $250^{\circ} \mathrm{C}$, og opvarmet til $450^{\circ} \mathrm{C}$. Efter hver af de nævnte behandlinger er nye röntgendiagrammer optaget. Fig. 2 viser en skematisk fremstilling af hele prøvebehandlingen. Et repræsentativt udsnit af prøverne blev behandlet med varm, fortyndet $\mathrm{HCl}$ for at opløse den tilstedeværende klorit. Enkelte udvalgte prøver er endvidere behandlet med opløsninger af kalium- og magnesiumsalte for at kunne undersøge lermineralernes expansionsevne.

De enkelte lermineralgruppers relative andel af det samlede lermineralindhold er bestemt efter de metoder, Johns, Grim og Bradley (1954) og Schultz (1960) har udarbejdet. Disse metoder har, som alle andre benyttede metoder, visse begrænsninger, men de er valgt, fordi de er relativt hurtige og simple at arbejde med, og de giver et lettere overskueligt billede af lermineralgruppernes fordeling, når det drejer sig om undersøgelser af et stort antal prøver.

\section{Mineralogi.}

Resultaterne af lermineral-analyserne er gengivet i tabellerne 2 til 9, og i figurerne 3 til 9 er vist en række typiske röntgendiagrammer. Variationen i lermineralsammensætning gennem den undersøgte, stratigrafiske serie vises i figur 10.

Montmorillonit-gruppens mineraler er de dominerende lermineraler i de fleste af de undersøgte prøver. Mange af prøverne indeholder desuden varierende mængder af lermineraler fra kaolin-, illit- og mixed-layer-grupperne.

Den undersøgte aflejringsserie kan på grundlag af lermineralsammensætningen opdeles i tre zoner. De tre zoner, karakteriseret ved deres lermineralogiske sammensætning, er fra yngst til ældst:

(a) Zone III indeholder i varierende mængder mineraler fra grupperne montmorillonit, illit og kaolin samt mixed-layer mineraler af typen montmorillonit-illit.

(b) Zone II består hovedsagelig af amorft materiale, og montmorillonit-, illit- og kaolin-mineraler er kun til stede i små mængder.

(c) Zone I er karakteriseret ved et stort indhold af montmorillonit-mineraler. Underordnede mængder - eller blot spor - af illit- og mixed-layer-mineraler har kunnet påvises, men kaolin-gruppens mineraler mangler.

En sammenligning mellem lermineral-analyserne af prøverne fra zone III giver grund til at tro, at zonen på grundlag af lermineralindholdet kan opdeles i 4 underzoner. Underzone III-D (yngst) indeholder en noget varierende blanding af montmorillonit-, kaolin- og illit-mineraler. Underzone III-C har et dominerende indhold af mixed-layer-mineraler. Underzone III-B indeholder relativt mere kaolin end illit, mens det i underzone III-A er illit-indholdet, der er relativt større end kaolin-indholdet. Adskillelsen mellem underzone III-B og underzone III-A er altså baseret på kaolin- og illit-mineralernes indbyrdes mængdemæssige fordeling.

I tabel 10 er lermineral-sammensætningen i de enkelte zoner sat i relation til stratigrafien.

\section{Diskussion.}

Lermineralselskabet og variationerne heri kan være af hængig af et eller flere af følgende tre almindelige forhold: oprindelsesmaterialets natur samt omfanget og arten af den forvitring, der er foregået deri; processer der er foregået under og efter transport og aflejring som folge af det skiftende milieu; og endelig den recente for- 
vitring. Lermineral-sammensætningen i de undersøgte sedimenter er søgt vurderet $\mathrm{i}$ relation til disse forhold.

Muligheden for, at den påviste lermineral-sammensætning er et resultat af recente forvitringsprocesser, kan på forhånd ikke udelukkes. Hvis betydningsfulde ændringer er foregået som følge heraf, skulle lermineralindholdet i de prøver, der er indsamlet på eller nær overfladen, imidlertid tydeligt afvige fra lermineralindholdet i de boreprøver, der er optaget fra aflejringer under forvitringszonen. Boreprøver fra Lillebælt ler, Søvind mergel og septarieler indgik i undersøgelserne, og disse prøvers lermineral-sammensætning afviger ikke fra sammensætningen i de prøver, der er indsamlet på eller nær overfladen. For disse tre lerarters vedkommende kan man derfor antage, at den recente forvitring ikke har nogen afgørende indflydelse på mineralsammensætningen. Boreprøver af Lellinge grønsand, Kerteminde ler, Røsnæs ler og øvre oligocæn ler var ikke tilgængelige, og en lignende kontrol kunne derfor ikke foretages.

Lermineral-indholdet i zone I antages at være forvitringsprodukter, der stammer fra de ældre kalkaflejringer, der har omgivet det skandinaviske område. Det relativt store indhold af montmorillonit-mineraler kan være opstået som følge af diagenetiske processer i det marine milieu og/eller gennem en sortering af materialet ved aflejringen.

Mo-leret med dets ledsagende askelag i zone II afspejler en afgørende ændring i den geologiske udvikling i den danske del af Nordsø-bassinet. BøGGILD (1918, p. 32), ANDersen (1937a, p. 51) og Norin (1940, p. 37) har påvist vulkansk aktivitet med center i det nordlige Skagerrak. De vulkanske askelag kan følges så langt mod syd som til det nordvestlige Tyskland. Den vulkanske aktivitet må formodes også at være afspejlet i mo-lerets lermineralindhold, men ingen af de röntgen-undersøgelser, der er udført af UNMACK (1949) og af forfatteren, giver helt afgørende holdepunkter. Materialet er helt overvejende af amorf karakter, og blandt de tilstedeværende lermineraler dominerer montmorillonit-gruppen, mens kaolin- og illit-gruppernes mineraler kun er til stede i ringe mængde. De påviste lermineraler må dog anses for at være opstået ved omdannelse af vulkansk materiale.

Den større variation i lermineral-sammensætningen inden for zone III er et udtryk for ændringer - efter den eocæne vulkanisme - i de områder, hvorfra materialet stammer. Det store indhold af montmorillonit kan være opstået ved omdannelse af vulkansk aske, der er aflejret i havet, og/eller det kan være dannet ved forvitring og erosion i land-aflejret, vulkansk materiale. Kaolin-mineralerne i Zone III er antagelig resultatet af feldspat-forvitring, og stigningen i kaolinindholdet inden for zonen kan sættes i forbindelse med en stadig mere fremskreden forvitring på landoverfladen. Forskellen mellem lermineral-sammensætningerne i underzone III-A og underzone III-B skyldes derfor, at der er sket en mere gennemgribende omdannelse af oprindelsesmaterialet. Mixed-layer mineralerne af montmorillonit-illit typen, der er påvist i underzone III-C, må ligeledes henføres til en meget fremskreden forvitring, der har fundet sted i oprindelsesbjergarterne, inden forvitringsmaterialet er transporteret til aflejringsstedet.

Variationerne i lermineral-sammensætning i zone III kan endvidere sættes i forbindelse med fysiske ændringer i transport- og aflejringsforholdene. Det stigende indhold af kaolin- og illit-mineraler kan således være afhængig af ændringer i transportlængde, vanddybde og strømforhold. Skiftende klimatiske forhold og ændringer i det marine milieu er yderligere faktorer, der kan have haft stor indflydelse. 
Trods de fremførte usikkerheds-faktorer giver röntgen-undersøgelserne af de danske, paleogene sedimenter grund til at tro, at bjergarternes lermineral-indhold kan sættes i relation til forholdene i oprindelsesområdet og til de væsentlige ændringer, der skyldes fysiske og kemiske betingelser i aflejringsområdet.

Denne undersøgelsesrække har ikke kunnet udstrækkes over et endnu større område, men de allerede fundne, indbyrdes forskellige lermineral-selskaber giver dog et mineralogisk mønster, som sammen med resultater af andre undersøgelser kan tjene til at forklare den geologiske udvikling. 


\section{References Cited}

D. G. U. - Danmarks Geologiske Undersøgelse, Copenhagen.

M. D. G. F. - Meddelelser Dansk Geologisk Forening, Copenhagen.

Andersen, S. A., 1937. De vulkanske askelag i vejgennemskæringen ved Ølst og deres udbredelse i Danmark: D.G.U., II. r. nr. 59, p. 5-50 (with English summary).

BøGGILD, O. B., 1918. Den vulkanske aske i Moleret samt en oversigt over Danmarks ældre Tertiærbjærgarter: D.G.U., II. r. nr. 33, p. 1-142 (with French summary).

Bradley, W. F., 1954. X-ray diffraction criteria for the characterization of chloritic material in sediments, p. 324-334 in Clays and clay minerals: Natl. Acad. Sci.-Natl. Res. Council, pub. 327, 498 p. - Washington D. C.

Brown, G. and MacEwan, D. M. C., 1951. X-ray diffraction by structures with random interstratification, p. 266-284, in Brindley, G. W., X-ray identification and crystal structures of clay minerals: Mineralog. Soc. Great Britain Mon. 345 p. - London.

Burst, J. F., 1958. "Glauconite" pellets: their mineral nature and application to stratigraphic interpretations: Amer. Assoc. Petroleum Geol. Bull., v. 42, p. 310-327. Tulsa, Oklahoma.

Bysтröм, А. M., 1956. Mineralogy of the Ordovician bentonite beds at Kinnekulle, Sweden: Sveriges Geol. Undersökning, ser. C, N: O 540, 62 p. - Stockholm.

Clausen, H., 1932. Røntgenografiske undersøgelser af danske lerarter: M. D. G. F., bd. 8 , p. $167-174$.

Droste, J. B., 1961. Clay minerals in sediments of Owens, China, Searles, Panamint, Bristol, Cadiz, and Danby Lake basins, California: Bull. Geol. Soc. Amer., v. 72, p. 1713-1721. - New York.

Graff-Petersen, P., 1955. Lillebæltler, en lermineralogisk undersøgelse: M. D. G. F., bd. 13, p. 1-14 (with English summary).

Griffin, G. M. and Ingram, R. L., 1955. Clay minerals of the Neuse River Estuary: Jour. Sed. Pet., v. 25, p. 194-200. - Tulsa, Oklahoma.

Grim, R. E., 1953. Clay mineralogy: N.Y., McGraw-Hill Book Co., Inc., 384 p. - New York.

Grim, R. E., 1958. Concept of diagenesis in argillaceous sediments: Amer. Assoc. Petroleum Geol. Bull., v. 42, p. 246-253. - Tulsa, Oklahoma.

Grim, R. E. and Bradley, W. F., 1955. Structural implications in diagenesis: Geologisches Rundschau, band 43 , heft 2, p. 469-474. - Stuttgart.

Gry, H., 1935. Petrology of the Paleocene sedimentary rocks of Denmark: D. G. U., II. r. $\mathrm{nr} .61,171 \mathrm{p}$.

Illies, H., 1949. Die Lithogenese des Untereozäns in Nordwestdeutschland: Mitt. Geol. Staatsinstitut in Hamburg, heft 18, p. 7-44. - Hamburg.

Johns, W. D., Grim, R. E., and Bradley, W. F., 1954. Quantitative estimations of clay minerals by diffraction methods: Jour. Sed. Pet., v. 24, p. 242-251. - Tulsa, Oklahoma.

Keller, W. D., 1956. Clay minerals and environment: Amer. Assoc. Petroleum Geol. Bull., v. 40, p. 2689-2710. - Tulsa, Oklahoma.

Madsen, V., 1902. Beskrivelse til geologisk kort over Danmark: Kortbladet Nyborg. D. G. U., I. r. nr. 9, 182 p. (with French summary).

Murray, H. H. and Harrison, J. L., 1956. Clay mineral composition of Recent sediments from Sigsbee Deep: Jour. Sed. Pet.. v. 26, p. 363-368. - Tulsa, Oklahoma.

Norin, R., 1934. Zur Geologie der Südschwedischen Basalte: Medd. Lund. Geol.-Mineral. Inst., no. 57, 174 p. - Lund, Sweden.

Norin, R., 1940. Problems concerning the volcanic ash layers of the lower Tertiary of Denmark: Medd. Lund. Geol.-Mineral. Inst., no. 78, p. 31-44. - Lund, Sweden.

Ponder, H., and Keller, W. D., 1960. Geology, mineralogy and genesis of selected fireclays from Latah County, Idaho, p. 44-62 in Clays and clay minerals: Eighth Natl. Conf. on Clays and Clay Minerals Proc., Pergamon Press, 292 p. - London. 
Ross, C. S., Miser, H. D. and Stephensen, L. W., 1929. Waterlain volcanic rocks of early upper Cretaceous age in southwestern Arkansas, southeastern Oklahoma, and northeastern Texas: U.S. Geol. Survey Prof. Paper 154-F, p. 175-202. - Washington D.C.

Ross, C. S. and Hendricks, S. B., 1945. Minerals of the montmorillonite group, their origin and relation to soils and clays: U.S. Geol. Survey Prof. Paper 205-B, p. 23-79. - Washington D. C.

Schultz, L. G., 1960. Quantitative x-ray determinations of some aluminous clay minerals in rocks, p. 216-224 in Clays and Clay Minerals: Seventh Natl. Conf. on Clays and Clay Minerals Proc., Pergamon Press, 369 p. - London.

Sorgenfrei, T., 1957. Europe; Danemark: Lex. Strat. Internat., vol. 1, fasc. 2 d, 44 p. Paris.

Unмаск, A., 1944. Resultater af nyere lerundersögelser: Kgl. Vetr. Landbohsk. Aarsskr., p. 33-59. - Copenhagen.

UnMACK, A., 1949. X-ray investigation of some Danish clays II, montmorillonitic clays: Kgl. Vetr. Landbohsk. Aarsskr., p. 192-204. - Copenhagen.

VALETON, I., 1959. Eine vulkanische Tufflage aus der Oberkreide von Hemmoor/Niederelbe: Neues Jb. Geol. u. Paläont., Mh. heft 5, p. 193-204. - Stuttgart.

Valeton, I., 1960. Vulkanische Tuffiteinlagerung in der nordwestdeutschen Oberkreide; Mitt. Geol. Staatsinstitut in Hamburg, heft 29, p. 26-41. - Hamburg.

Weaver, C. E., 1953. Mineralogy and petrology of some Ordovician K-bentonites and related limestones: Geol. Soc. America Bull., v. 64, p. 921-943. - New York.

Weaver, C. E., 1958a. The effects and geologic significance of potassium "fixation" by expandable clay minerals derived from muscovite, biotite, chlorite and volcanic material: Amer. Min., v. 43, p. 839-861. - Menasha, Wisconsin.

Weaver, C. E., 1958b. A discussion on the origin of clay minerals in sedimentary rocks, p. 159-173 in Clays and clay minerals: Natl. Acad. Sci.-Natl. Res. Council, pub. 566,360 p. - Washington, D.C.

Weaver, C. E., 1959. The clay petrology of sediments, p. 154-187, in Clays and clay minerals: Sixth Natl. Conf. on Clays and Clay Minerals Proc., Pergamon Press, 411 p. - London.

Whitehouse, V. G. and Jefrrey, L. M., 1955. Peptization resistance of selected samples of kaolinitic, montmorillonitic, and illitic clay materials, p. 260-281 in Clays and clay minerals: Natl. Acad. Sci.-Natl. Res. Council, pub. 395, 573 p. - Washington D. C. 
Denne bog er sat med Monotype Fredericus Antiqua og trykt i 1500 eksemplarer på Andelsbogtrykkeriet i Odense. Papir: ekstraglittet 605, 125 g, fra De forenede Papirfabrikker. 